\title{
KRAŠTO APSAUGOS DEPARTAMENTAS IR JO VEILLA 1990-1991 M.
}

Dr. Gintautas Surgailis

Generolo Jono Žemaičio Lietuvos karo akademija

\section{Méginimas ịkurti Krašto apsaugos ministeriją}

1998 m. birželio mèn. Lietuvos inteligentijos pastangomis įkurtas Lietuvos persitvarkymo sajūdis pradèjo pertvarkos procesus Lietuvoje. $1990 \mathrm{~m}$. vasari vykusiuose rinkimuose i Lietuvos TSR Aukščiausiąją Tarybą Sajūdžio kandidatai laimèjo absoliučią daugumą vietu, jų dèka 1990 m. kovo $11 \mathrm{~d}$. buvo priimtas Lietuvos valstybès atkūrimo aktas, kuriuo buvo paskelbta, kad Lietuva vèl yra nepriklausoma valstybè. Buvo pradėta formuoti Kazimieros Prunskienès vadovaujama Lietuvos Vyriausybè. Tačiau Nepriklausomybę dar reikejo įtvirtinti, pasiekti tarptautinị pripažinimą, perimti į savo rankas valstybės sienų kontrolę, organizuoti krašto ir jo žmoniu gynimą. Tai buvo galima pasiekti tik sukūrus krašto apsaugos sistemą, tuo labiau kad nuo pat pirmuju Nepriklausomybės dienų Sovietų Sajunga prieš Lietuvą pradèjo šaltajji karą. Siekiant apsunkinti Lietuvos santykius su kaimynais, prasidejo Lietuvos politinè izoliacija ir skaldymas. Kad galètu ịsikišti SSRS represinès tarnybos, mėginta sudaryti konfliktines situacijas, suformuoti nacionalistinès, į diktatūrą linkusios valstybès įvaizdị.

Nesitenkinant tuo, $1990 \mathrm{~m}$. balandžio 19 d. buvo pradèta vykdyti ekonominès blokados politika, siekiant sužlug- 
dyti Lietuvos ekonomiką, sukurstyti žmonių nepasitenkinimą, suformuoti neigiamą požiūrị ic nepriklausomos valstybės kūrimą, įbauginti gyventojus, pakirsti pasitikëjimą Lietuvos valdžia ir jos institucijomis, sukelti bejégiškumo jausmą ir sudaryti prielaidas grịžti į valdžią Maskvos statytiniams.

Lietuvos istoriografijoje apie atkurtos Lietuvos valstybès kariuomenès kūrimo pradžią nèra daug publikacijų, todèl straipsnis parašytas daugiausia remiantis dokumentais, saugomais Krašto apsaugos archyve prie Krašto apsaugos ministerijos, oficialiais Aukščiausiosios Tarybos - Atkuriamojo Seimo ir Vyriausybės dokumentais, Aukščiausiosios Tarybos - Atkuriamojo Seimo stenogramomis, spaudos publikacijomis. Iš spaudos leidinių reikètų išskirti Krašto apsaugos ministerijos žurnalą „Karys“, Lietuvoje vèl pradėtą leisti 1991 m. sausio mèn., kuriame yra daug faktinès medžiagos apie to meto įvykius.

Nemažai medžiagos suteikė 1990-1991 m. Krašto apsaugos departamento darbuotojai. Iš publikuotų darbu reikètu atskirai paminėti „Konferencijos "Lietuvos krašto apsaugos sistemos atkūrimas" medžiagą "1. Šiame straipsnių rinkinyje yra nemažai faktinès medžiagos apie Krašto apsaugos departamento istoriją.

1990 m. kovo 23 d. Lietuvos Respublikos Aukščiausioji Taryba pirmą kartą bande įkurti valstybès apsaugos instituciją tvirtindama ministrus. Ministrè Pirmininkè Kazimiera Prunskienè krašto apsaugos ministru siūle skirti Lietuvos Respublikos Aukščiausiosios Tarybos deputatą Vidmantą Povilionị. Pristatydama kandidatą į krašto apsaugos ministrus Ministré Pirmininkè Vidmantas Povilionis pabrèžè, kad „būtent tokios tarny-

${ }^{1}$ Konferencijos „Lietuvos krašto apsaugos sistemos atkūrimas“ medžiaga. - Vilnius, 2000. 
bos, būtent tokį ministrą, kaip krašto apsaugos, Respublikos valstybingumui arba savarankiškos valstybès Vyriausybei tvirtinti tikrai reikia“2.

Ši Ministrès Pirmininkès siūlymą nemažai Aukščiausiosios Tarybos deputatų sutiko priešiškai. Siūlymui įkurti Krašto apsaugos ministeriją pirmasis pasipriešino deputatas Egidijus Bičkauskas. Jis, pateikdamas klausimą K. Prunskienei, pareiškè, kad, jo „giliu ịsitikinimu, visu tuo, kas vyksta ir ko reikia, turi užsiimti vidaus reikalu ministras ${ }^{\text {“3. }}$.

Deputatu požiūris iš esmès nepasikeite ir po V. Povilionio kalbos, kurioje jis išdèste pagrindinę krašto apsaugos kūrimo koncepciją. Śios deputatų nuostatos pagrindinę priežastị atskleidè deputatas Juozas Tamulis. Kandidatui į krašto apsaugos ministrus duodamas klausimą jis pabrèžè: „Visų pirma norèčiau priminti gerbiamajam kandidatui, kad Sąjūdžio rinkiminëje platformoje buvo aiškiai parašyta: ne tik neutrali, bet ir demilitarizuota" .

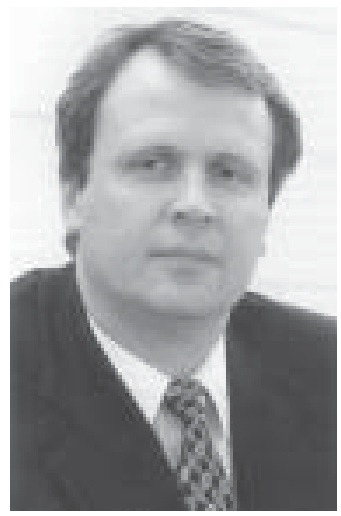

Albinas Januška

Deputatė Nijolė Oželytė-Vaitiekūnienè pareiškè, jog ,turèti iliuziju, kad galima suburti kariuomenę, galinčią kam nors rimtai pasipriešinti, yra juokinga". Ji siūlè tik sudaryti pasienio dalinius ${ }^{5}$. Deputatas Vidmantas Žiemelis siūlè visai nevartoti termino „kariuomené“. Tai, deputato nuomone, gali pakenkti valstybei, kuri siekia pripažinimo $^{6}$, o deputatas Albinas Januška buvo labai kategoriškas. Jis pareiškè: „,Man atrodo, kad šitas klausimas visiškai neparengtas.Visa ta diskusija kaip kaž-

${ }^{2}$ Lietuvos Respublikos Aukščiausiosios Tarybos (pirmojo šaukimo) pirmoji sesija. $1990 \mathrm{~m}$. kovo 21-23 d. Stenogramos. - Lietuvos Respublikos Aukščiausioji Taryba. - Vilnius, 1991. P. 317.

${ }^{3}$ Ten pat. - P. 317

${ }^{4}$ Ten pat. - P. 320.

${ }^{5}$ Ten pat. - P. 324-325.

${ }^{6}$ Ten pat. - P. 325. 
koks klaikus nakties sapnas. (Plojimai.) Aš kalbėsiu ultimatyviai. Siūlau nutraukti klausimo svarstymą. Jeigu vis dèlto klausimas bus siūlomas balsuoti, manau, kad bus deputatu, kurie išeis iš salès ir sukels kvorumo krizę ${ }^{\prime \prime 7}$.

Reikia pripažinti, kad A. Januška dèl daug ko buvo teisus. Klausimas iš tikruju nebuvo parengta svarstyti. Pretendentas į ministrus kalbèjo gana aštriai. Kaip paaiškejjo diskusiju metu, jo išdėstyta gynybos koncepcija nebuvo aptarta su Ministre Pirmininke ir jau paskirtais ministrais, pagaliau ir pats pretendentas pasirode menkai išmanąs karinius dalykus, painiojo netgi terminus, pvz., šaukimą i kariuomenę ir mobilizaciją .

Deputatų A. V. Patacko, A. Januškos, K. Uokos siūlymu šio klausimo svarstymas buvo atidètas, kol parlamente bus aptartas strateginis krašto apsaugos sistemos pobūdis ${ }^{9}$.

Aiškiai matant Aukščiausiosios Tarybos nusistatymą, krašto apsaugos ministro kandidatūros pakartotinis svarstymas nebuvo inicijuotas.

\section{Krašto apsaugos departamento ịkūrimas}

Žinant antikarines Aukščiausiosios Tarybos deputatu nuostatas buvo nuspręsta, kad vèl siūlyti svarstyti krašto apsaugos ministro kandidatūrą neverta. Buvo pasirinktas kitas būdas - įkurti Krašto apsaugos departamentą prie Lietuvos Respublikos Vyriausybès. Tačiau reikia pažymèti, kad to priežastis buvo ne vien antikarinès Sajūdžio deputatų daugumos nuostatos. Buvo pareikšta ir tokia nuomonè: kad dar labiau nesuerzinus SSRS, apie karinių struktūrų kūrimą apdairiau būtų kol kas apskritai viešai nediskutuoti - geriau pradèti kurti kokią nors struktūra, kuri nesukeltų stiprios neigiamos reakcijos. Ko gero, atsižvelgus i abi minètas nuomones ir buvo nuspręsta kurti Krašto apsaugos departamentą (KAD).

\footnotetext{
${ }^{7}$ Ten pat. - P. 325.

${ }^{8}$ Ten pat. - P. 318-320.

${ }^{9}$ Ten pat. - P. 327.
} 


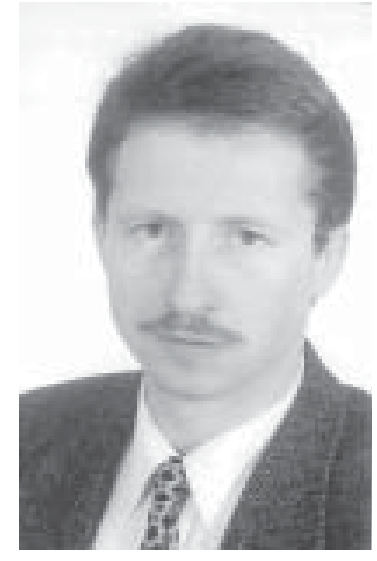

Audrius Butkevičius

1990 m. balandžio 25 d. Lietuvos Respublikos Vyriausybès sprendimu buvo įsteigtas Krašto apsaugos departamentas. Krašto apsaugos departamento generaliniu direktoriumi paskirtas Aukščiausiosios Tarybos deputatas Audrius Butkevičius.

Departamentui buvo iškeltas uždavinys - formuoti ir igyvendinti krašto apsaugos koncepciją, sukurti krašto apsaugos sistemą.

1990 m. gegužès 17 d. Vyriausybės nutarime buvo detalizuotos pagrindinès Krašto apsaugos departamento veiklos kryptys. Departamentas buvo ịpareigotas teikti siūlymus Lietuvos Respublikos Vyriausybei dèl krašto apsaugos, užsienio ir vidaus politikos, rengti įstatymu, susijusių su krašto apsauga, bei kitu teisés aktu projektus, kontroliuoti Vyriausybės pavestus tarptautinius įsipareigojimus, planuoti krašto apsaugos sistemos darbą, kurti būtinas, kad ji galètų funkcionuoti, tarnybas, prižiūrèti jų veiklą, iggyvendinti Lietuvos Respublikos Aukščiausiosios Tarybos ir Vyriausybès sprendimus krašto apsaugos srityje; rengti mobilizacinius kariuomenès ir valstybès planus, krašto apsaugos planą, rūpintis mobilizacinių išteklių rengimu ir apskaita, karine įskaita, spręsti jaunuoliu karo tarnybos klausimus, rengti siūlymus dèl ju alternatyviosios tarnybos; palaikyti ryšius su savivaldybiu padaliniais ir ministerijomis, atsakingais už mobilizacinių išteklių apskaitą, skirstymą, šaukimo į kariuomenę organizavimą; rūpintis specialistu, reikalingų krašto apsaugos sistemai, rengimu, ugdyti Lietuvos Respublikos gyventoju pilietinę ir patriotinę savimonę, kuruoti visuomeniniu sporto organizacijų bei ju gamybiniu padalinių veiklą; rinkti ir analizuoti informacija, susijusią su krašto apsaugos veikla, rengti siūlymus dèl SSRS ginkluotuju pajègu, dislokuotų Lietuvo- 
je, statuso ir kt., deryboms su SSRS Vyriausybe; rūpintis kariuomenès veteranais, karių ir jų šeimų socialiniais reikalais; kontroliuoti produkcijos SSRS ginkluotuju pajègų dalims, dislokuotoms Lietuvos Respublikos teritorijoje, tiekimą; derinti SSRS ginkluotuju pajègu perdislokavimo, karinių manevru, organizuojamu už karinių bazių ribų, klausimus; rengti deryboms su SSRS Vyriausybe gynybinių interesų srityje siūlymus dèl SSRS ginkluotuju pajegu, dislokuotu Lietuvos Respublikos teritorijoje, statuso ir kt. ${ }^{10}$

Departamento nuostatai buvo patvirtinti tik $1991 \mathrm{~m}$. rugsejjo $27 \mathrm{~d}$. Juose atsispindejo pirmiau minètos svarbiausios departamento veiklos kryptys, teisès ir pareigos ${ }^{11}$.

\section{Centrinio KAD aparato formavimas}

Buvo numatyta, kad įkurtame Krašto apsaugos departamente dirbs 38 darbuotojai. Departamentui buvo išnuomotos patalpos Vilniuje, Kosciuškos g. $36^{12}$, ir skirtas minimalus finansavimas ${ }^{13}$.

Kol nebuvo įsikèlęs i patalpas Kosciuškos gatvëje, departamentas dirbo Aukščiausiosios Tarybos Nacionalinio saugumo komiteto skirtuose dviejuose Aukščiausiosios Tarybos rūmų kabinetuose. I naujas patalpas departamentas persikèlè tik $1990 \mathrm{~m}$. birželio $1 \mathrm{~d}$. Jose buvo tik 7 kabinetai.

Didžiausia departamento aparato formavimo našta užgulè generalinio direktoriaus pečius. Jau vèliau, prisimindamas tas dienas, "Respublikos" dienraščio žurnalistui jis pasakojo: „Kai atėjau i krašto apsauga, man niekas nepasakè, ką aš turiu daryti. Ir dabar nesako. Kurk, Butkevičiau, krašto

\footnotetext{
${ }^{10}$ Dèl Lietuvos Respublikos Vyriausybès departamentų pagrindinių funkcijų. Lietuvos Respublikos Vyriausybès nutarimas // Lietuvos Respublikos Aukščiausiosios Tarybos ir Vyriausybès žinios. - 1990. - Nr. 18. - P. 563-564 .

${ }^{11}$ Dèl Krašto apsaugos departamento prie Lietuvos Respublikos Vyriausybès nuostatu patvirtinimo. Lietuvos Respublikos Vyriausybès nutarimas // Ten pat. - 1991. - Nr. 30. - P. $1453-1457$.

${ }^{12} \mathrm{~A}$. Butkevičiaus 1990 m. gegužès 28 d. raštas Vilniaus miesto tarybai // Krašto apsaugos ministerijos einamasis archyvas (toliau - KAMEA). - F. 1. - Ap. 1. - B. 11. - L. 2.

${ }^{13}$ Paužolis J. LAKS'o indèlis Lietuvos kariuomenès 1990-1991 metų atkūrimui. Pranešimas, skaitytas 20000211 konferencijoje Krašto apsaugos karininkų ramoveje.
} 
apsaugą pagal savo paveikslą, kaip Dievas. Galiu pasidžiaugti savarankiškumu. Nors nuolat galvoju ir apie atsakomybę. Nepasitaręs aš stengiuosi nepriimti sprendimų ${ }^{\prime \prime 14}$.

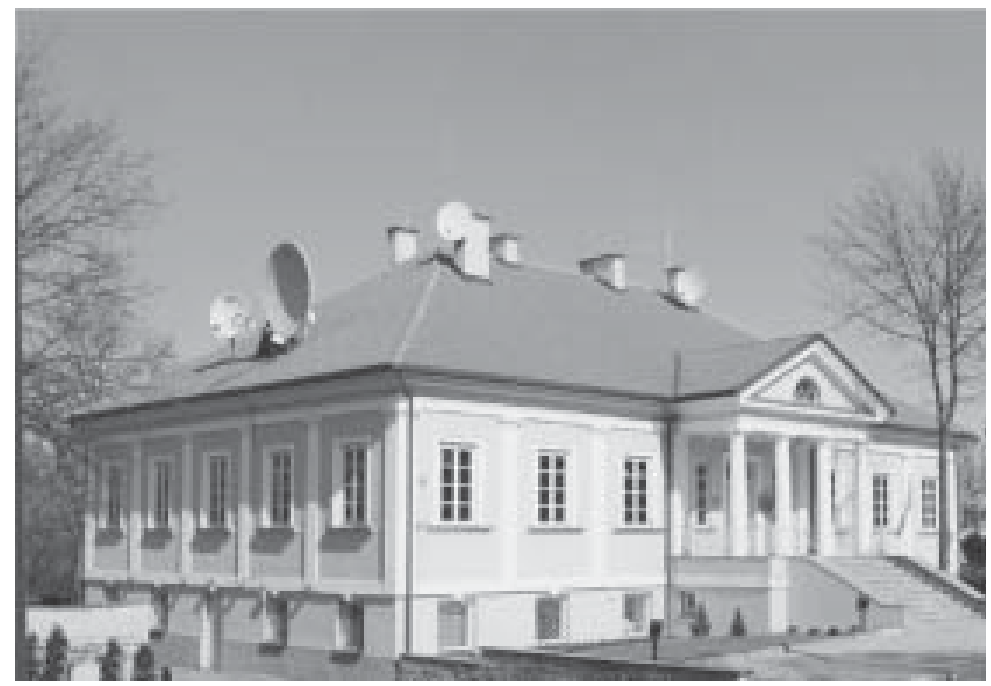

Pirmasis KAD pastatas Kosciuškos g. 36

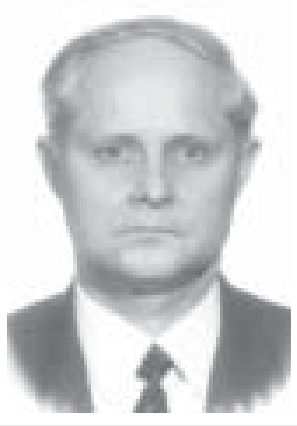

Algimantas Vaitkaitis

1990 m. gegužès 22 d. A. Butkevičius Kauno medicinos instituto Karinès katedros viršininkui Algimantui Vaitkaičiui pasiūlè tapti jo pavaduotoju. Šiam sutikus, kitą dieną jis buvo pristatytas Aukščiausiosios Tarybos Prezidiumo Pirmininkui Vytautui Landsbergiui ir Ministrei Pirmininkei Kazimierai Prunskienei. 1990 m. gegužès 24 d. Lietuvos Respublikos Vyriausybės nutarimu Algimantas Vaitkaitis buvo paskirtas Krašto apsaugos departamento generalinio direktoriaus pavaduotoju ${ }^{15}$.

\footnotetext{
${ }^{14}$ Pranašystès slenkančio pavojaus fone // Respublika. - 1991, rugsėjo 13.

${ }^{15}$ Vaitkaitis A. Tèvynès labui. Pranešimas, skaitytas 20000211 konferencijoje Krašto apsaugos karininkų ramoveje; Lietuvos Respublikos Vyriausybės 1990 m. gegužės 24 d. nutarimas Nr. 163 // Krašto apsaugos archyvas prie Krašto apsaugos ministerijos (toliau - KAA).
} 
Darbą pradejjo nedidelis bendraminčių būrelis. Buvo nusibrèžtos kelios svarbiausios darbo kryptys: sukurti specialiąsias tarnybas, galinčias apginti Lietuvos Respublikos interesus, pasienio ekonominès apsaugos tarnybą, svarbiu valstybinių objektų bei įstaigu apsaugos tarnybas, Respublikos civilinès saugos sistema, kurti Lietuvos kariuomenès, tada planuotos kaip nacionalinè gvardija, padalinius.

Esant Lietuvoje labai sudètingai situacijai, vienas iš sudètingiausių departamentui iškilusių uždavinių buvo pradèti rengti Lietuvos vyrus profesionaliai Lietuvos gynybai. 1990 m. pavasari, Lietuvai dar nesulaukus tarptautinio pripažinimo, atvirai to daryti buvo beveik neįmanoma, todèl nutarta šį darbą dirbti prisidengus karinio-techninio sporto klubo iškaba. 1990 m. gegužès 31 d. Krašto apsaugos departamento generalinio direktoriaus įsakymu Nr. 1 prie Krašto apsaugos departamento buvo įkurtas toks klubas. Klubo viršininku paskirtas Česlovas Jezerskas ${ }^{16}$. Tačiau buvo aišku, kad tai yra tik trumpalaikè priemone.

Pradèta priimti i̇ departamentą darbuotojus. $1990 \mathrm{~m}$. gegužès $18 \mathrm{~d}$. generalinio direktoriaus patarejja buvo priimta Rosita Daunoravičiūtè ${ }^{17}$. Persikèlus i naujas patalpas, nuo birželio 1 d. oficialiai buvo priimti: Jonas Paužolis - Pirmojo skyriaus viršininku, Franciška Žinienè - vyriausiaja ekonomiste-finansininke, Rimvydas Vaitiekūnas - ūkvedžiu-tiekèju, Šarūnas Vasiliauskas - Ketvirtojo skyriaus I kategorijos inžinieriumi, Paulius Bartkus - Antrojo skyriaus inspektoriumi, Klemensas Radzevičius - Pirmojo skyriaus inspektoriumi jaunuolių apskaitai, Petras Maštavičius - Pirmojo skyriaus inspektoriumi (kadrų), Artūras Merkys - generalinio direktoriaus patarejju, Litauras Paužolis - Pirmojo skyriaus inspektoriumi, Alfonsas Bajoras - Antrojo skyriaus viršininku, Jonas Gečas - KAD archyvo vedejju (puse etato), Ričar-

\footnotetext{
${ }^{16} \mathrm{KAD} 1990$ m. gegužès 21 d. įsakymas Nr. 1 // Krašto apsaugos departamento generalinio direktoriaus isakymų rinkinys. - 1990. - P. 3.

${ }^{17} \mathrm{KAD}$ generalinio direktoriaus įsakymas dèl priëmimo ị darbą // KAA. - F. 1. - Ap.2. - B. 1 . - L. 2.
} 
das Pocius - Ketvirtojo skyriaus I kategorijos techniku, Kęstutis Treigys - Ketvirtojo skyriaus I kategorijos techniku, Jonas Simanavičius - vairuotoju ${ }^{18}$. Nuo birželio $11 \mathrm{~d}$. KAD buhaltere priimta Janina Garuolytė, 12 d. Antrojo skyriaus inspektoriumi-koordinatoriumi - Jonas Vytautas Žukas ${ }^{19}$.

İkurtas Krašto apsaugos departamentas jam keliamu uždaviniu vien tik su Vilniuje esančiomis struktūromis igyvendinti negalëjo. Buvo kreiptasi į Vyriausybę, siūlant Lietuvos miestuose ir rajonuose kurti KAD skyrius. 1990 m. gegužès $24 \mathrm{~d}$. Lietuvos Vyriausybè sutiko su departamento siūlymu mobilizaciniams ištekliams ruošti, skirstyti, ju apskaitai tvarkyti, jaunuoliu karo tarnybos klausimams spręsti miestuose ir rajonuose ikurti Krašto apsaugos departamento skyrius arba turèti atskirus darbuotojus, išlaikomus iš Lietuvos valstybės biudžeto ${ }^{20}$.

1990 m. birželio 1 d. buvo įsteigti KAD skyriai septyniose zonose:

1) Alytaus (Alytaus m., Alytaus, Lazdiju, Varėnos r.);

2) Kauno (Kauno m., Kauno, Jonavos, Jurbarko, Kaišiadoriu, Kèdainiu, Raseiniu, Prienu r.);

3) Klaipėdos (Klaipėdos m., Klaipėdos, Kretingos, Mažeikių, Plungès, Skuodo, Šilalès, Śilutès r.);

4) Marijampolès (Marijampolès m., Marijampolès, Šakių, Vilkaviškio r.);

5) Panevėžio (Panevėžio m., Panevėžio, Anykščiu, Biržu, Kupiškio, Pasvalio, Rokiškio, Utenos, Zarasų r.);

6) Šiauliu (Šiauliu m., Šiauliu, Akmenès, Joniškio, Kelmès, Pakruojo, Radviliškio, Tauragès, Telšių r.);

7) Vilniaus (Vilniaus m., Vilniaus, Ignalinos, Molètu, Traku, Salčininku, Širvintu, Švenčionių, Ukmergès r. $)^{21}$.

\footnotetext{
${ }^{18}$ Krašto apsaugos generalinio direktoriaus įsakymai dẻ prièmimo ị darbą // Ten pat. - L. 8-11, 14-17, 21, 24, 29-32, 33-34, 38.

${ }^{19}$ Ten pat. - L. 19, 27.

${ }^{20}$ Dèl Krašto apsaugos departamento organizacinių klausimų. Lietuvos Vyriausybès nutarimas // Lietuvos Respublikos Aukščiausiosios Tarybos ir Vyriausybès žinios. - 1990. - Nr. 17. - P. 535. ${ }^{21} \mathrm{KAD} 1990$ m. birželio 1 d. ịsakymas Nr. 2 // Krašto apsaugos departamento generalinio direktoriaus įsakymų rinkinys. - 1990. - P. 3
} 
1990 m. lapkričio 15 d. buvo ịkurta nauja Utenos zona, todèl teritoriją teko perskirstyti taip:

1) Alytaus (Alytaus m., Alytaus, Lazdiju, Varénos r.);

2) Kauno (Kauno m., Kauno, Jonavos, Kaišiadoriu, Raseiniu, Prienų r.);

3) Klaipèdos (Klaipėdos m., Klaipėdos, Kretingos, Mažeikiu, Plungès, Skuodo, Šilalès, Tauragès, Šilutès r.);

4) Marijampolès (Marijampolès m., Marijampolès, Jurbarko, Šakių, Vilkaviškio r.);

5) Panevėžio (Panevėžio m., Panevėžio, Anykščiu, Biržu, Kupiškio, Pasvalio, Rokiškio r.);

6) Šiauliu (Šiaulių m., Šiauliu, Akmenès, Joniškio, Kelmès, Pakruojo, Radviliškio, Telšių r.);

7) Utenos (Utenos, Ignalinos, Molètų, Švenčionių, Zarasų r.);

8) Vilniaus (Vilniaus m., Vilniaus, Traku, Šalčininku, Širvintu, Ukmergès r. $)^{22}$.

Nuo birželio $1 \mathrm{~d}$. Klaipėdos zonos viršininku buvo paskirtas Cirilis Norkus, Šiaulių zonos - Zigfridas Orentas, Kauno zonos - Vytautas Baranauskas ${ }^{23}$. Nuo birželio 4 d. Panevėžio skyriaus viršininku paskirtas Antanas Dulevičius, nuo birželio $18 \mathrm{~d}$. Marijampolès zonos viršininku - Vytautas Jurgis Kadžys, nuo liepos 2 d. Alytaus zonos viršininku Liubartas Ragelis ${ }^{24}$.

Pradejus intensyvų Krašto apsaugos departamento kūrimo darbą greitai paaiškẻjo, kad darbuotojų reikės daugiau, negu buvo numatyta. Jau 1990 m. liepos 30 d. Vilniaus mieste, Krašto apsaugos departamente, dirbo 51 žmogus ${ }^{25}$, lapkričio 30 d. $-61^{26}$.

\footnotetext{
22 Dèl Lietuvos Respublikos teritorijos paskirstymo ị Krašto apsaugos departamento veiklos zonas. KAD 1990 m. lapkričio 15 d. ịsakymas Nr. 24 //Ten pat. - P. 10-11.

${ }^{23}$ Krašto apsaugos generalinio direktoriaus įsakymai dèl priemimo į darbą // KAA. - F. 1. - Ap. 2. - B. 1. -L. 29-30, 41.

${ }^{24}$ Ten pat. - L. 28, 35, 36.

${ }^{25}$ KAD 1990 m. liepos 30 d. raštas Vilniaus m. prekybos organizacijų valdybai // KAA. - F. 1. - Ap. 1. - B. 16. - L. 56.

${ }^{26}$ KAD 1990 m. lapkričio 29 d. raštas Vilniaus miesto prekybos organizacijų valdybai // Ten pat. - L. 191.
} 
İ Krašto apsaugos departamentą dirbti atėjo labai įvairių žmoniu, tarp jų nemažai buvusių sovietinės armijos ir jau išejusiu i c atsargą karininkų. Jie daugiausia buvo deleguoti Atsargos karininkų sajungos. Buvo nemažai aktyvių Sajūudžio veikeju, savo atstovus delegavo Politiniu kalinių ir tremtinių sajunga. Dauguma pirmuju darbuotoju buvo gana jauni. Be abejo, absoliuti dauguma atejusiuju i i departamentą buvo tikri Lietuvos patriotai, nes tuo metu dirbti šioje struktūroje buvo iš tikruju pavojinga.

İkūrus Krašto apsaugos departamentą, naują karinę struktūrą, pradèjus ị jị priimti žmones, būtinai reikèjo sukurti krašto apsaugos tarnybą reglamentuojančius įstatymus. Dar vykstant rinkimams į Lietuvos Aukščiausiają Tarybą dauguma kandidatu i i deputatus žadejo, jog visą atsakomybę už tai, kad Lietuvos jaunuoliai neis į sovietinę kariuomenę, prisiims parlamentas. $1990 \mathrm{~m}$. balandžio $4 \mathrm{~d}$. buvo priimtas Lietuvos Respublikos Aukščiausiosios Tarybos kreipimasis į Lietuvos jaunuolius. Jame pabrèžta: "Jūsų demokratiškai išrinktas parlamentas, šių metų kovo 11 dieną atstatęs savo Tèvynès garbę ir orumą, tiki, kad Jūs, neidami tarnauti į svetimos valstybės kariuomenę, stiprinsite Lietuvos nepriklausomybę. Visuotinis Lietuvos piliečiu atsisakymas tarnauti būtų dar vienas žygis Lietuvos nepriklausomybès labui.

Nors Lietuvos valdžia negali jėga apginti jaunuoliu nuo prievartinio rekrutavimo, tačiau ji imasi juridinès ir moralinès atsakomybės už savo valstybès piliečių atsisakymą tarnauti svetimiems $<\ldots>^{1 / 27}$.

Paskelbus ši kreipimąsi, iškilo problema, kaip padaryti, kad Aukščiausioji Taryba ir Vyriausybè realiai prisiimtų atsakomybę už šių žmonių likimą. Krašto apsaugos departamento vadovų nuomone, kurią palaike ir Lietuvos Vyriausybė, tai turejjo garantuoti priimtas Lietuvos Respublikos laikinasis krašto apsaugos įstatymas.

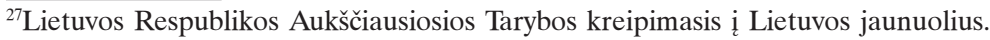


Šio įstatymo projektą rengė pats departamentas. 1990 m. birželio 13 d. KAD generalinis direktorius A. Butkevičius įstatymo projektą pristatė Aukščiausiajai Tarybai. Ji pristatydamas A. Butkevičius pažymëjo: „Neįmanoma apginti žmogaus ir neįmanoma netgi ruošti jo gynimo, jeigu mes nesame pareiškę i ji ji kažkokių savo teisių. Kadangi iš Tarybu Sajungos pusès yra reiškiamos teisès ir pretenzijos į šitą pati žmogu, jis yra šaukiamas į Tarybinę armiją, iš mūsų pusès taip pat turètų būti nuostata dèl šito žmogaus tolesnio likimo. Tokia nuostata ir gali būti suformuluota Lietuvos Respublikos krašto apsaugos įstatyme ir Lietuvos Respublikos krašto apsaugos prievolès įstatyme <...> Tokiu atveju, jeigu Lietuvos Respublikos piliečiai taptų Lietuvos Respublikos krašto apsaugos prievolininkais ir būtu pašaukti į Lietuvos Respublikos krašto apsaugos tarnybą, duotu priesaiką Lietuvos Respublikai, būtų labai sunku paaiškinti jų èmimą i Tarybu Sajungos ginkluotąsias pajejgas. Netgi tokiu atveju, jeigu šitas žmogus būtu paimtas prievarta, žymiai palengvètų jo gynimas, kadangi šitoki žmogu būtų galima traktuoti jau netgi kaip karo belaisvị “28.

Pateiktame projekte, be kita ko, buvo numatyta, kad tinkami tarnybai jaunuoliai gali atlikti tikrają karo tarnybą arba alternatyviajją darbo tarnybą. Šaukti į tarnybą buvo numatoma 19 metu jaunuolius, tačiau i ją galejjo stoti ir sulaukusieji 18 metu (todèl, kad 18-mečiai buvo šaukiami į SSRS karo tarnybą). Siūloma tarnybos trukmé - pusantru metų ${ }^{29}$.

\footnotetext{
${ }^{28}$ Lietuvos Respublikos Aukščiausiosios Tarybos (pirmojo šaukimo) pirmoji sesija. Stenogramos.T. 9.- V., 1991. - P. 439-440.

${ }^{29}$ Ten pat. - P. 441.
} 


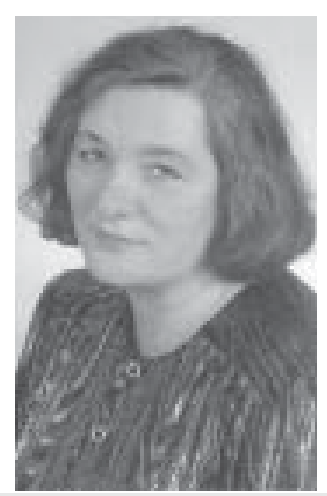

Vidmantė Jasukaitytė

Projektą Aukščiausiosios Tarybos deputatai sutiko gana priešiškai. Deputatas V. Jermolenka iš principo pasisakė prieš ši projektą, laikydamasis „piliečiu teisès arba laisvès teisès principü. P. Tupikas prieštaravo, kad būtų šaukiami 19 metų jaunuoliai, siūlè šaukti 18-mečius. Deputatui V. Andriukaičiui atrodè, kad projektas yra parengtas pagal Sovietų Sajungos karinę doktriną. V. Jasukaitytè manè, jog reikètú vis dèlto palikti „vietos požiūriui, kad žmogus būtinai turètų turèti teisę iš viso atsisakyti bet kokios tarnybos, tiek alternatyviosios, tiek ne, jeigu jis gyvenimo kelią pasirenka visai kitą“. E. Vilko nuomone, projektas pateiktas svarstyti ne laiku, per anksti ${ }^{30}$.

Baigdamas pristatyti įstatymo projektą A. Butkevičius pareiškè: „Aš labai gerai suprantu, jog daugelis iš čia esančių ir toliau norètų neprisiimti atsakomybės už šaukiamojo amžiaus jaunuolių likimą ir šitą atsakomybę perduoti Krašto apsaugos departamentui. Mes tokią atsakomybę priimame. Tačiau jeigu parlamentas nepateiks aiškios nuomonės dèl šaukiamojo amžiaus jaunuoliu, aš nemanau, kad mūsų darbas bus efektyvus" ${ }^{31}$.

Tuo metu įstatymas nebuvo priimtas.

1991 m. birželio 21 d. Aukščiausiosios Tarybos posèdyje buvo pristatyti Lietuvos Respublikos krašto apsaugos tarnybos ir Krašto apsaugos prievolès įstatymų projektai. Istatymų projektus pristate Aukščiausiosios Tarybos Pirmininko pavaduotojas Česlovas Stankevičius.

Krašto apsaugos departamento pateiktą įstatymo projektą Aukščiausiosios Tarybos Prezidiumas suskirstė ị du. Lietuvos Respublikos krašto apsaugos tarnybos įstatymo projektas gimė Aukščiausiosios Tarybos Prezidiumo iniciatyva.

${ }^{30}$ Ten pat. - P. $442-445$.

${ }^{31}$ Ten pat. - P. 447. 
Jame buvo siūloma, kaip reikia spręsti bendruosius krašto apsaugos tarnybos klausimus, o antrajame - Krašto apsaugos prievolès - įstatyme detalizuojama, kaip ta tarnybos prievolè yra organizuojama, atliekama, kaip nuo jos atleidžiama.

Pristatydamas projektus Č. Stankevičius pažymëjo, jog jie yra apsvarstyti Valstybès atkūrimo komisijos atvirame posèdyje ir daugelis ten dalyvavusių deputatu pasisakè už tai, kad Lietuva, kaip neutrali valstybè, dètų minimaliai pastangų ir skirtų lëšų krašto apsaugos kariniams daliniams kurti ateityje, kad jos saugumas būtu grindžiamas tarptautinėmis garantijomis, o ne tik savomis ginkluotosiomis pajejgomis.

Pateikti įstatymu projektai gerokai skyrèsi nuo anksčiau KAD pateikto projekto. Projekte buvo fiksuojama norma, kad šaukiamojo pageidavimas yra lemiamas pasirenkant tarnybos rūšį. Buvo išbraukti visi straipsniai, kuriuose kalbama apie tarnybą karo metu ir kitus dalykus, kurie nesusiję su tuometinemis krašto apsaugos tarnybos reikmėmis.

Projektų svarstymas buvo gana aštrus. Iš esmès, padarius kai kuriuos pataisymus, projektams siūle pritarti deputatai A. Patackas, A. Norvilas. Deputatas J. Karvelis pritare pirmajam projektui, o antrojo įstatymo projektą siūle atidèti. Kiti diskusijose kalbejję deputatai kategoriškiau ar ne taip kategoriškai pasisakè prieš. Deputatas R. Gudaitis, be kita ko, pareiškè, kad svarstomi įstatymai „,apgins naujujų karininkų antpečius, algas ir padèti - sutinku. Kad bus užtikrinta jaunuoliu ir visos Lietuvos apsauga - drịsčiau suabejoti <...> Nenoréčiau, kad Lietuvą, be ekonominių bėdu, slègtų dar ir saldofoniškos pretenzijos, militaristiniai prietarai“/32.

Deputato A. Januškos nuomone, „iš viso antrojo projekto nedera čia svarstyti, o dèl projekto, kuris liečia krašto apsaugos tarnybą, tai yra projekto, kuri pateike Prezidiumas, ten yra pasakyta, kad tai - laikinas projektas. Tačiau visiškai neapibrèžta, kada baigiasi tas laikinumas ${ }^{\prime 33}$.

${ }^{32}$ Lietuvos Respublikos Aukščiausiosios Tarybos (pirmojo šaukimo) pirmoji sesija. Stenograma. T. - 10. - V., 1991. - P. 200-201.

${ }^{33}$ Ten pat. - P. 203. 
Deputate V. Jasukaitytė iš karto pareiškè, kad kritiškai vertina abu įstatymu projektus. Jos nuomone, Krašto apsaugos departamentas nesuvokia Lietuvos kaip visiškai neutralios valstybės ateities ${ }^{34}$.

J. Tamulis manè, kad kariuomenè Lietuvai dèl jos geopolitinès padèties yra visiškai nereikalinga ${ }^{35}$.

K. Lapinsko nuomone, Krašto apsaugos departamentas turètu pirmiausia rūpintis tam tikrų ginkluotų arba sukarintų būrių formavimu savanoriškumo principu, o ne visuotinès karo tarnybos prievolès įvedimu ${ }^{36}$.

P. Vaitekūnas ši į̧statymo projektą vertino panašiai kaip ir R. Gudaitis -,,ne kaip ginantį Lietuvą, bet ginantį Krašto apsaugos departamento interesus, ginanti jo etatus ir leidžiantị iš principo daryti politiką jèga, iš jẻgos pozicijų ${ }^{\prime \prime 3}$.

Balsuojant už šiuos projektus, dauguma deputatų balsavo prieš, o svarstymas buvo atidètas iki atskiro nutarimo ${ }^{38}$.

$1990 \mathrm{~m}$. liepos 17 d. po pakartotinio svarstymo buvo priimtas Laikinasis krašto apsaugos prievolès įstatymas. Tai, be abejo, buvo svarbus įvykis. Tačiau nebuvo sukurta geru savu įstatymu, ir tai labai trukde kuriant pačią Krašto apsaugos sistemą, nes dar tebegaliojo ir senieji sovietiniai įstatymai. Jie oficialiai nebuvo panaikinti, todėl Krašto apsaugos departamento vadovai bet kada galëjo būti apkaltinti neteisètais veiksmais.

1990 m. rugpjūčio mèn. KAD vadovybè nusprendè įurti KAD Apsaugos tarnybą. Buvo parengtas Apsaugos tarnybos nuostatu projektas, tipinè individuali darbo sutartis, numatyta prièmimo ị šį darbą tvarka. Rugpjūčio $18 \mathrm{~d}$. su šiuo pasiūlymu buvo kreiptasi į Aukščiausiają Tarybą ir Vyriausybę ${ }^{39}$.

Sumanymui buvo pritarta ir $1990 \mathrm{~m}$. rugpjūčio $21 \mathrm{~d}$., vadovaujantis Lietuvos Respublikos Vyriausybès $1990 \mathrm{~m}$.

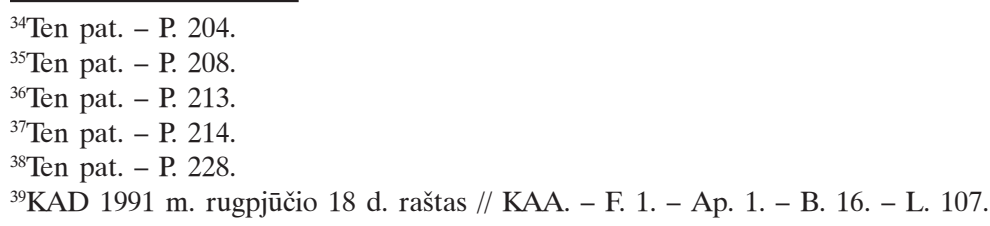


rugpjūčio 20 d. potvarkiu „Dèl Apsaugos tarnybos prie KAD įsteigimo", buvo ịkurta Krašto apsaugos departamento Apsaugos tarnyba ${ }^{40}$. Pagal nuostatus tai buvo Krašto apsaugos departamento ūkiskaitinis sukarintas padalinys, saugantis ypač svarbius Lietuvos Respublikos objektus. Remiantis tarpžinybinès komisijos išvadomis buvo sudaromos objektu apsaugos sutartys. Šios komisijos išvados būdavo pateikiamos objekto apžiūros akte. Objektų apsaugos sutartis Krašto apsaugos departamento vardu sudarydavo Apsaugos tarnybos viršininkas. Sutartys buvo sudaromos metams, tačiau galejjo būti nutrauktos ir anksčiau vienos iš šaliu pageidavimu.

Pagrindiniai uždaviniai, keliami apsaugos tarnybai, garantuoti esamų materialinių vertybių apsaugą, neilleisti i saugomą objektą pašalinių asmenu, vykdyti Lietuvos Vyriausybès skirtas užduotis.

Apsaugos tarnyba buvo formuojama savanoriškumo principu. I ją buvo priimami 19-35 m. Lietuvos piliečiai, nepriklausantys jokioms politinėms partijoms, mokantys valstybinę kalbą ir pagal savo asmenines ir dalykines savybes, sveikatą tinkantys šiai tarnybai. Be to, jie su Krašto apsaugos departamentu sudarydavo terminuotas darbo sutartis.

Siekiant patikrinti, ar pareiškęs norą asmuo tinkamas tarnauti apsaugos tarnyboje, buvo nustatytas tam tikras laikotarpis, kuris baigdavosi kandidatui išlaikius specialiu žiniu patikrinimo egzaminą.

Apsaugos tarnybos darbuotojams kaip kraštutinę priemonę buvo leista naudoti ginklą.

Kiekvienu ginklo panaudojimo atveju Apsaugos tarnybos darbuotojai privalèjo informuoti savo vadovybę, imtis priemonių, kad sužeistajam būtų suteikta skubi medicinos pagalba.

Šaunamajji ginklą buvo draudžiama naudoti prieš asmenis, turinčius su savimi mažamečiu vaiku, prieš moteris ir nepilnamečius, taip pat prieš asmenis, turinčius aiškių in-

${ }^{40} \mathrm{KAD} 1990 \mathrm{~m}$. rugpjūčio $21 \mathrm{~d}$. įsakymas Nr. 12 // Krašto apsaugos departamento generalinio direktoriaus įsakymų rinkinys. 1990 m. - P. 6. 
validumo požymiu, išskyrus atvejus, kai jie ginkluoti užpuola arba priešinasi ginklu ${ }^{41}$.

Apsaugos tarnybos nuostatai Lietuvos Respublikos Ministrès Pirmininkès pavaduotojo R. Ozolo buvo patvirtinti 1990 m. spalio $3 \mathrm{~d}$.

1990 m. rugsëjo 10 d. Lietuvos Vyriausybè, siekdama apsaugoti Lietuvos rinką ir pradèti kontroliuoti Lietuvos sienas, prièmè nutarimą „Dèl papildomų laikinų priemonių Lietuvos Respublikos rinkai apsaugoti“. Šiuo nutarimu buvo pavesta nuo $1990 \mathrm{~m}$. spalio $1 \mathrm{~d}$. pradėti Lietuvos muitinès veiklą, formuoti Krašto apsaugos departamento tarnybas Lietuvos Respublikos sienos ekonominei apsaugai užtikrinti, sukurti jų veiklai būtiną materialinę techninę bazę.

Lietuvos Respublikos sienos ekonominei apsaugai organizuoti ir Lietuvos muitinès veiklai su kaimyninèmis valstybemis koordinuoti buvo sudaryta darbo grupè: A. Butkevičius, M. Laurinkus, R. Purtulis, S. D. Umbrasas, V. Zabarauskas ir Lietuvos Respublikos vyriausiasis muitininkas ${ }^{42}$.

Taigi departamentui buvo iškeltas labai sudètingas uždavinys, nes vienas iš valstybingumo požymių yra savų sienu kontrolè, o to SSRS jokiu būdu nenorejjo leisti. Departamentas turejo imti saugoti $1747 \mathrm{~km}$ sausumos sienos, kurią kirto 253 įvairių kategoriju keliai, $99 \mathrm{~km}$ ilgio jūros sieną, oro erdvę. Sienos su Latvija ilgis - 650 km, su Lenkija - 103, su Rusijos Federacija - $255 \mathrm{~km}$. $44 \mathrm{~km}$ siena èjo upèmis, $29 \mathrm{~km}$ ežerais, $163 \mathrm{~km}$ - pelkėmis, $422 \mathrm{~km}$ - miškais. Ji kirto 61 upę ir upeli, 166 kelius, 32 tiltus, 16 geležinkeliu.

Aptarti, kaip bus vykdomas minėtas Vyriausybės nutarimas, 1990 m. rugsëjo 19 d. Krašto apsaugos departamente buvo surengtas išplèstinis tarnybinis pasitarimas. I pasitarimą buvo sukviesti zonų ir rajonų KAD instruktoriai. Pasitarime buvo aptarti konkretūs veiksmai ir priemonès ${ }^{43}$.

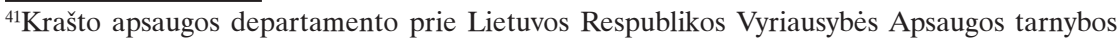
nuostatai // KAMEA

${ }^{42}$ Valstybès žinios. - 1990, Nr. 27-668.

${ }^{43}$ Norkus C. Tèvynès labui. - P. 97.
} 
Kad būtų galima įvykdyti ši nutarimą, buvo numatyta įrengti 64 Krašto apsaugos departamento Pasienio apsaugos tarnybos pasienio kontrolès postus. Pagal KAD generalinio direktoriaus įsakymą lapkričio $19 \mathrm{~d}$. jie jau turèjo pradèti darbą. Iki tos dienos turéjo būti įrengti pasienio kontrolès postai, tarnybinès patalpos ${ }^{44}$.

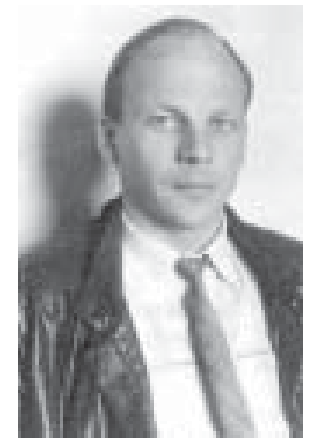

Virginijus Česnulevičius

Visiems pasienio darbams vadovauti Krašto apsaugos departamente buvo sukurtas Pasienio apsaugos tarnybos skyrius. Jo viršininku buvo paskirtas Virginijus Cesnulevičius. Jam ir teko pagrindiniai pasienio apsaugos kūrimo rūpesčiai.

Pasienio apsaugos tarnyba pagal Laikinają Krašto apsaugos departamento pasienio apsaugos tarnybos instrukciją turëjo tikrinti asmenu, įmoniu, įstaigǔ, organizaciju išvežamas už Lietuvos Respublikos ribu prekes pagal ribojamu ir draudžiamu piliečiams išvežti iš Lietuvos Respublikos maisto ir ne maisto prekių sąrašus, leidimus prekèms iš Lietuvos išvežti, patikrinti juose nurodytą prekių kieki, vežamų kroviniu plombas, teikti pagalbą Vidaus reikalų ministerijos darbuotojams išaiškinant nusikaltimus, sulaikant nusikaltèlius, informuoti Vidaus reikalų ministeriją apie pastebètus ar sulaikytus iztartinus asmenis ar transporto priemones ${ }^{45}$.

Pavedimui įvykdyti reikëjo nemažai lèšų ir žmonių, o parinkti tinkamus pasienio apsaugos pareigūnus irgi buvo ne taip jau paprasta. Tinka ar netinka parinktas asmuo tarnybai, nuspręsdavo šiam tikslui $1990 \mathrm{~m}$. spalio $15 \mathrm{~d}$. sudaryta mandatinė prièmimo į darbą Pasienio apsaugos tarnyboje komisija. Komisijos pirmininku buvo paskirtas J. Paužolis, nariais - V. Česnulevičius, V. Žukas, P. Maštavičius bei kon-

\footnotetext{
${ }^{44}$ Dèl pasienio kontrolès postų išstatymo. KAD 1990 m. lapkričio 15 d. įsakymas Nr. 25 // Krašto apsaugos departamento generalinio direktoriaus įsakymų rinkinys. 1990 m. - P. 11 . ${ }^{45}$ Laikinoji Krašto apsaugos departamento Pasienio apsaugos tarnybos instrukcija // KAMEA. - F. 1. - Ap. 2.- B. 30. - L. 7 a.p.
} 
krečios KAD zonos skyriaus viršininkas ${ }^{46}$. Spalio 22 d. šios komisijos sudètis buvo pakeista. I ją dar buvo įtraukti A. Bajoras, A. Dulevičius ir L. Paužolis. Ši komisija buvo padalyta i dvi darbo grupes ${ }^{47}$.

Pasienio tarnyba buvo formuojama labai sparčiai, tačiau beveik nuo pat pirmujų darbo dienu pasieniečiai susidūrẻ su nemažais sunkumais. Pagal nustatytą struktūrą pasienio 4 pareigūnu patrulio tarnybos pamaina turejjo kontroliuoti 30-40 km pasienio ruožą. Neturintys mašinų ir neginkluoti pasieniečiai jiems iškeltas užduotis galëjo atlikti tik formaliai ${ }^{48}$. Nebuvo tinkamai suderintas juridinis pasieniečių statusas, rūpesčių kèlè nepatenkinamos buities ir tarnybos sąlygos, maži eilinių ir kai kurių vidurinių grandžiu pareigūnu atlyginimai, neišspręsta butų ir kai kurios kitos problemos. Nepaisant to, pirmieji pasieniečiai garbingai atliko savo pavojingos tarnybos pareigas.

Pradejus saugoti sienas iškilo labai rimta problema kaip elgtis su valstybės sieną kertančiomis SSRS karinėmis mašinomis, kurias neretai lydėdavo ginkluoti kariai. Siekiant išvengti ginkluotų susidūrimų, realiai įvertinus Lietuvos padèti, iki to laiko, kol derybose su Maskva bus išspręstas Lietuvoje dislokuotų SSRS karinių pajėgų statuso klausimas, Pasienio apsaugos tarnybos pasienio apsaugos postams buvo įsakyta netikrinti išvažiuojančių iš Lietuvos SSRS ginkluotųju pajègu transporto priemonių ir jų krovinių ${ }^{49}$.

Toks sprendimas buvo logiškas ir priimtas laiku, nes SSRS kariškiai, Krašto apsaugos departamentui pradejjus kontroliuoti sienas, reagavo labai priešiškai. Pirmiausia viešus protestus Lietuvos Vyriausybei pradejo reikšti SSRS VSK Pabaltijo pasienio apsaugos viršininkas gen. ltn. V. Gaponen-

\footnotetext{
${ }^{46}$ Dèl mandatinès komisijos sudarymo. 1990 m. spalio 15 d. KAD įsakymas Nr. 18 // Krašto apsaugos departamento generalinio direktoriaus įsakymų rinkinys. 1990 m.- P. 9.

${ }^{47}$ Ten pat.

${ }^{48} 1991$ m. sausio 30 d. KAD generalinio direktoriaus raštas Lietuvos Respublikos Vyriausybei // KAMEA.

${ }^{49} \mathrm{KAD} 1990$ m. gruodžio 19 d. įsakymas // Krašto apsaugos generalinio direktoriaus įsakymu rinkinys. 1990 m. - P. 16.
} 
ko. Svarbiausias jo protestu motyvas - niekas neturi teisės iqvesti SSRS valstybès sienos kontrolès ir pan. ${ }^{50}$

1990 m. gruodžio 20 d. Kaune buvo įsteigti Karininku kursai. Apie kursų organizavimą pradèta galvoti nuo tada, kai tik buvo įkurtas departamentas. Jau 1990 m. gegužès mėn. KAD generalinis direktorius patvirtino Krašto apsaugos karininkų ruošimo programą. Buvo numatytas 260 valandų kursas. Planuota dèstyti šiuos dalykus: politologiją, taktiką, žvalgybą, priešcheminę apsaugą, Lietuvos kariuomenès statutus, šaudybą ir ginklus, karinę topografiją, inžinerini parengimą, pirmosios medicinos pagalbos pradmenis, asmens higieną ir fizinį lavinimą.

1990 m. liepos mènesį Kaune susibūrę atsargos karininkai ir aukštuju mokyklų dèstytojai iškèlè mintį rengti kvalifikuotus karininkus besikuriančiai Lietuvos kariuomenei. Idejją palaikè KAD generalinis direktorius A. Butkevičius ir jo pirmasis pavaduotojas A. Vaitkaitis ${ }^{51}$.

Tačiau kursų steigimo operatyvinè grupè pradejjo dirbti tik 1990 m. lapkričio 15 d. Ją sudarè Bronislovas Vizbaras, Jonas Veselka, Vytautas Latkauskas, Algis Liorentas, Povilas Skrivelis, Kazimieras Skrinska, Algimantas Jurevičius, Arūnas Virbila, Žygimantas Lapènas ${ }^{52}$.

Karininku kursu viršininku buvo paskirtas Bronislovas Vizbaras. B. Vizbaras įsakymu kursų viršininko pavaduotoju mokymo reikalams paskyrė J. Veselką, Finansu tarnybos viršininku - A. Liorentą, kursų viršininko pavaduotoju užnugariui - V. Latkauską, Inžinerinèspionieriu tarnybos viršininku - A. Virbilą, dėstytojais K. Skrinką, P. Skvirelį, A. Jurevičiu, intendantu-Ž. Lapėną ${ }^{53}$.

I Karininku kursus buvo priimami Lietuvos piliečiai, turintys atsargos karininko ar praporščiko laipsni, ne vyresni kaip $30 \mathrm{~m}$. amžiaus, teigiamai charakterizuojami darbe,

\footnotetext{
${ }^{50}$ V. Gaponenkos 1990 m. gruodžio 25 d. raštas K. Prunskienei // KAMEA.

${ }^{51}$ Vizbaras B. Karininkų kursai ir Div. gen. S. Raštikio puskarininkių mokyklos veikla // Konferencijos „Lietuvos krašto apsaugos sistemos atkūrimas“ medžiaga. - P. 115.

${ }^{52}$ Ten pat.

${ }^{53}$ Ten pat.
} 
dalyvaujantys visuomeninëje veikloje, įgiję Lietuvos valdžios organų ir visuomeninių organizaciju pasitikejjimą ${ }^{54}$.

I pirmają kursu laidą buvo priimti 47 klausytojai5 ${ }^{55}$.

Buvo nustatyta kursu trukmè -4 mènesiai. Kursams buvo atiduotos "Vyčio" organizacijos Kauno automokyklos patalpos. Darbas prasidejo $1991 \mathrm{~m}$. sausio 2 d., bet jau sausio 9 d. dauguma dèstytojų ir klausytojų išvyko į Vilnių ginti Aukščiausiosios Tarybos.

1990 m. rudenị įsteigtas KAD Informacijos skyrius. Jo uždavinys buvo rinkti žvalgybinius duomenis apie sovietu armijos dalinius, dislokuotus Lietuvoje ${ }^{56}$.

Susikūrus pagrindiniams departamento padaliniams, 1990 m. rugpjūčio 16 d. buvo sudaryta departamento kolegija, turinti patariamojo balso teisę sprendžiant svarbius departamento veiklos klausimus ir problemas. Kolegijos pirmininku tapo generalinis direktorius A. Butkevičius, pirmininko pavaduotoju - A. Vaitkaitis, nariais - J. Paužolis, A. Bajoras, A. Kairys, A. Pakalka ir J. Užurka ${ }^{57}$.

1990 m. spalio 12 d. į kolegiją buvo įtraukti A. Norvilas, C. Norkus, Z. Orentas ir G. Jurčiukonis ${ }^{58}$.

Kolegijos posėdžiuose buvo svarstomi svarbiausi departamento veiklos klausimai, krašto apsaugos sistemos plètros, specialistų paieškos, mokymo ir ugdymo, departamento padalinių sudarymo, jų veiklos ir likvidavimo,

\footnotetext{
${ }^{54}$ Dèl karininkų rengimo. KAD 1990 m. gruodžio 29 d. įsakymas Nr. 44 // Krašto apsaugos departamento generalinio direktoriaus įsakymų rinkinys. 1990 m. - P. 16 .

${ }^{55}$ Priimti: A. Bauža, R. Bertašius,V. Beržinskas, V. Bieliauskas, V. Dambrauskas, V. Dargužis, K. Didžiulis, J. Dusevičius, R. Gečas, A. Germanavičius, V. Giniotas, P. Grižas, S. Gusčius, M. Inkènas, J. Jasaitis, P. Jokubauskas, V. Jurevičius, G. Kabašinskas, G. Kastickas, A. Kliuka, V. Kibartas, R. Lenartavičius, S. Marcinkus, V. Margevičius, V. Navickas, V. Ostrauskas, V. Pontežis, E. Pupšys, A. Rastokas, V. Reklaitis, V. Rupšys, R. Ruzgys, A. Sirvydis, S. Stražinskas, A. Šedys, K. Šermukšnis, V. Šilas, K .Šipkinas, K.Šukys, S. Titas, A. Tumpa, V. Ubartas, V. Velavičius, A. Vilinauskas, S. Zavarauskas, A. Žukas, V. Žvinklys // KAA. - F. 1. - Ap. 2. - B. 40. - L. 20-21.

${ }^{56}$ Yra tokia tarnyba // Karys. - 1998.- Nr. 42. - P. 3.

${ }^{57} \mathrm{KAD} 1990$ m. rugpjūčio 16 d. įsakymas Nr. 11 // Krašto apsaugos departamento generalinio direktoriaus įsakymų rinkinys. 1990 m. - P. 5.

${ }^{58}$ Dèl Krašto apsaugos departamento kolegijos sudarymo. KAD 1990 m. spalio 12 d. įsakymas Nr. 17 // Ten pat. - P. 8.
} 
finansu, materialinių vertybiu paskirstymo, panaudojimo ir atsakomybès už jas, departamentui pavaldžiu tarnybu bei atskirų darbuotoju veiklos klausimai, įsakymų, nutarimu, statutu, svarbiausių dokumentų projektai.

Kolegijos sprendimai buvo priimami balsuojant, o ifforminami generalinio direktoriaus įsakymais.

Kolegijos posedžiai paprastai vykdavo kartą per ménesi, o kai reikėdavo - ir dažniau.

1990 m. rudenį Aukščiausioji Taryba prièmè du labai svarbius krašto apsaugos plètrai įstatymus.

1990 m. spalio 16 d. Aukščiausioji Taryba prièmé Lietuvos Respublikos alternatyvios (darbo) tarnybos prievolès įstatymą. Pagal jị Lietuvos Respublikos piliečiai nuo 19 iki 27 metu, krašto apsaugos prievolininkai, kurie dèl savo įsitikinimų negali atlikti tikrosios krašto apsaugos tarnybos, atlieka alternatyviąją (darbo) tarnybą. Buvo nustatyta jos trukmè - 24 mėnesiai, baigusiuju aukštąsias mokyklas tarnyba turëjo trukti 12 mėnesių ${ }^{59}$.

Antrasis - Krašto apsaugos tarnybos - įstatymas buvo priimtas $1990 \mathrm{~m}$. lapkričio $20 \mathrm{~d}$.

1990 m. lapkričio 15 d. A. Butkevičius patvirtino laikinąją Krašto apsaugos departamento struktūrą. Pagal ją departamentas buvo suskirstytas i skyrius:

I - Mobilizacijos;

II - Informacijos-žvalgybos;

III - Karinės parengties ir specialistu ruošimo;

IV - Užnugario;

V - Pasienio apsaugos;

VI - Inžinerinès tarnybos;

VII - Informatikos;

Finansu apskaitos;

Kadru apskaitos ${ }^{60}$.

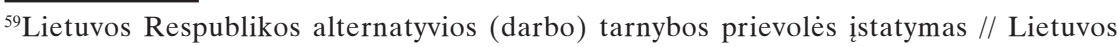
Respublikos Aukščiausiosios Tarybos ir Vyriausybès žinios. - 1991. - Nr. 30. - P. 1005-1008. ${ }^{60}$ KAA. - F. 1. - Ap. 1. - B. 12. - L. 1-4. 


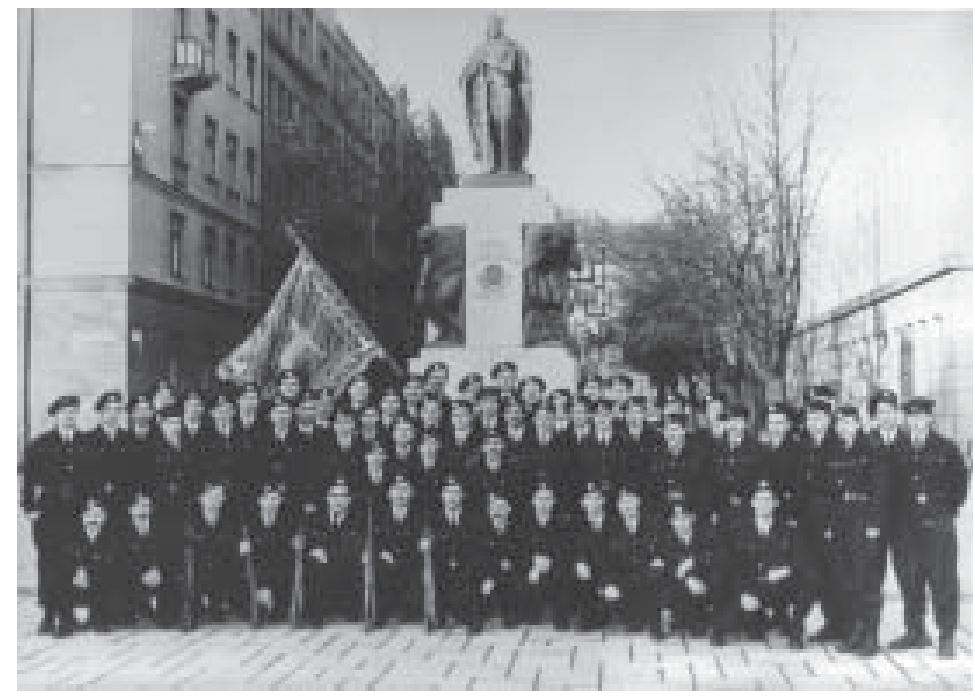

KAD darbuotojų grupè. 1990 m. lapkričio mėn. Kaunas (KASPA)

Tomis sunkiomis sąlygomis, kuriomis teko kurti Krašto apsaugos departamentą ir pradèti sudètingą krašto apsaugos sistemos kūrimo darbą, labai svarbus, bene vienas svarbiausiu, uždavinys buvo parinkti tinkamus kadrus. Pirmiausia sprendimus priimdavo pats generalinis direktorius. Tik vèliau, t. y. 1990 m. lapkričio 15 d., KAD kolegija nusprendè prie KAD sudaryti atestavimo komisiją, kuri siūlytų asmenis priimti į darbą, skirti karininku pareigoms. Ši komisija buvo sudaryta $1990 \mathrm{~m}$. gruodžio 3 d., jos pirmininku buvo paskirtas generalinio direktoriaus pavaduotojas A. Vaitkaitis, pavaduotoju - generalinio direktoriaus pavaduotojas I. Stankovičius, nariais - A. Kairys, B. Vizbaras, J. Paužolis, A. Bajoras, V. Žukas, N. Vidrinskas, A. Malijonis (A. Malijonis Lietuvos kariuomenès veteranas).

Komisija buvo įpareigota tikrinti karininku, norinčiu dirbti Krašto apsaugos departamente, žinias, ju kompetentingumą, anketinius duomenis ${ }^{61}$.

\footnotetext{
${ }^{61}$ Dèl atestacinès komisijos sudarymo. KAD generalinio direktoriaus $1990 \mathrm{~m}$. gruodžio $3 \mathrm{~d}$. ịsakymas // Krašto apsaugos departamento generalinio direktoriaus įsakymų rinkinys. 1990 m. -V., 1993. - P. 13.
} 
1990 m. gruodžio 6 d. Vyriausybės pavedimu Krašto apsaugos departamente buvo ịsteigtas Atskirasis apsaugos būrys $^{62}$. Būrio vadu paskirtas R. Baltušis. Būrys saugojo KAD pastatą, prižiūrëjo tvarką ịvairių renginių metu, mokési karybos pagrindu. Gruodžio pabaigoje būrys išaugo ii kuopą. Kuopos vadu buvo paskirtas Č. Jezerskas.

1991 m. sausio 2 d. kuopos vado įsakymu Nr. 1 į kuopą buvo priimti ir paskirti: A. Paužolis - kuopos vado pavaduotoju teoriniam ir praktiniam rengimui, R. Baltušis - kuopos vado pavaduotoju rikiuotei ir auklejjimui, K. Mickevičius kuopos gydytoju, P. Kasteckas - artimos kovos instruktoriumi, A. Mateika - Finansų skyriaus viršininku-iždininku, A. Pocius - instruktoriumi intendantu, R. Litvinas - priešcheminès apsaugos instruktoriumi, N. Misevičius - taktikos instruktoriumi, R. Gvazdauskas - I skyriaus vadu, R. Jonauskas - II skyriaus vadu, D. Skèraitis - III skyriaus vadu, B. Žilanas - IV skyriaus vadu, A. Budreika - V skyriaus vadu, A. Gvazdauskas VI skyriaus vadu, Š. Užusienis - VII skyriaus vadu, M. Adomènas - VIII skyriaus vadu, H. Prudnikas - IX skyriaus vadu, A. Stonkus - X skyriaus vadu, taip pat kariai ${ }^{3}$.

\footnotetext{
${ }^{62}$ A. Butkevičiaus 1991 m. sausio 29 d. raštas Lietuvos Respublikos Vyriausybei // KAMEA. F. 1. - Ap. 1. - B. 20. - L. 27.

${ }^{63}$ Kariais priimti: J. Kirkis, G. Vaickus, R. Dovidènas, D. Stakelskas, G. Kuncevičius, M. Jakutis, R.Tamašauskas, J. Markevičius, G. Liutkevičius, R. Takarevičius, K. Jurgelionis paskirti žvalgais, D. Pastarnokas, M. Rynkevičius, V. Giedraitis, S. Meidus, Ž. Svirnelis, S. Brazauskas, G. Rastenis, M.Dževečka, O. Imbrasas, J. Antanaitis - snaiperiais.

A. Putrimas, K. Lukošiūnas, A. Keršis, D. Miklušis, D. Šileikis, A. Panavas, T. Zabulis, R. Starkevičius, R. Barišauskas, R. Degulis paskirti sanitarijos instruktoriais, A. Čereška, R. Anglickas, A. Demenius, G. Skorupskis, M. Milevičius, R. Gudelaitis, M. Šmitas, D. Jasiulionis, T. Baratinskas, S. Daukšys - kulkosvaidininkais, D. Dagys, S. Sinkevičius, V. Ribakas, S. Vaštakas, S. Valadka, D.Chapko, G. Jonytis, P. Sokolovas, S. Vaikšnoras, V. Alekna - granatsvaidininkais, G. Ketleras, D.Panavas, M. Bajoraitis, L. Žilys, V. Pecinkevičius, V. Gackas, R. Taukinaitis, P. Petrikas, Ž.Sipovičius, Ž. Kaušyla - pionieriais.

S. Štelmokas, R. Klišis, A. Gaiževskis, R. Prokopovičius, S. Žerniauskas, R. Lanzbergas, R. Žabas, A. Kaziukonis, L. Žernius, S. Vilkišius buvo paskirti vairuotojais-šauliais,

S. Jašinskas, M. Birevičius, R Zaranka, M. Šternbergas, R. Misiūnas, Š. Gečas, M. Abaravičius, S. Repečka, L. Kavaliūnas, A. Petryla, D. Boguševičius, R. Moliejus, E. Čeponas, L. Guzikas, A. Kaminskas, T. Ušpolevičius, G. Čepukas, D. Kazaliauskas, V. Žulys, E. Grocheckis, R. Viržintas - eiliniais. // Dèl žmonių prièmimo ị Atskirąją apsaugos kuopą. Kuopos vado 1991 m. sausio 2 d. įsakymas Nr. 1 // KAMEA. - F. 1.- Ap. 2. - B. 117. - L. 1-2.
} 
1990 m. pabaigoje imta galvoti ir apie karinès aviacijos atkūrimą. Gruodžio $27 \mathrm{~d}$. KAD buvo įsteigtas aviatoriaus etatas. Audringomis $1991 \mathrm{~m}$. sausio dienomis į šias pareigas paskirtas lakūnas Zenonas Vegelevičius.

\section{Departamento veikla $1991 \mathrm{~m}$. sausio dienomis}

Lietuvos nepriklausomybės priešai nuo pat $1990 \mathrm{~m}$. kovo $11 \mathrm{~d}$. rengė rimtą tiek krašto apsaugos vyru, tiek visu Lietuvos žmonių išbandymą. Juo tapo $1991 \mathrm{~m}$. sausis, kai raudonieji okupantai ginkluota jèga mėgino užgniaužti Lietuvos žmonių ryžtą gyventi laisvai ir nepriklausomai. Krašto apsaugos departamento žvalgybos tarnyba dar iki sausio įvykiu gavo duomenu apie rengiamą pučą. Apie tai KAD generalinis direktorius įspejjo Lietuvos vadovybę ${ }^{64}$.

Antrają 1991-uju ų sausio savaitę įtampa dar labiau išaugo. Vis griežtesni Maskvos grasinimai, pastatų grobimas, smarkiai suaktyvëjusi "Jedinstvos" organizacijos veikla ir kita iš įvairiu šaltiniu gaunama informacija tik patvirtino jau turimas žinias apie artëjančią atvira, prieš Lietuvos valstybę nukreiptą agresiją.

Kariniuose aerodromuose nusileido 30 transportiniu lèktuvų IL-76 su desantininkais iš Pskovo. Milžiniška karinė kolona patraukė į Vilnių. Ankstų sausio 8-osios rytą tūkstančiai jedinstvininkų ir civiliniais drabužiais aprengtų kariškiu, nešinų raudonomis vẻliavomis ir transparantais su užrašais „Šalin vyriausybę!“, apsupo Aukščiausiosios Tarybos rūmus. Dalis jų įsiveržè į vidinị kiemeli ir pradëjo rūmų šturmą. Jiems pavyko išdaužti stiklus, išversti duris ir ịsiveržti į rūmus. Tik gynejjų atkalumas ir narsa, taip pat sėkmingai panaudoti priešgaisrinès sistemos vandens švirkštai padejo užpuolikus atremti. Prasidejjo derybos, o ị aikštę jau skubejjo vilniečiai, pasiryžę ginti Aukščiausiają Tarybą, ginti Nepriklausomybę. Aplink rūmus stichiškai prasidèjo barikadų statyba ${ }^{65}$.

\footnotetext{
${ }^{64}$ Pranašystès slenkančio pavojaus fone // Respublika. - 1991, rugsèjo 13.

${ }^{65}$ Gečas J. Viena praejjusio dešimtmečio savaitė // Karys.- 2000. - Nr. 8. - P. 8.
} 
Sausio 9 d. po vidurnakčio 308 kabinete susirinko Krašto apsaugos departamento darbuotojai ir buvo sudarytas Aukščiausiosios Tarybos rūmų gynybos štabas. Vadu tapo KAD generalinis direktorius Audrius Butkevičius, pavaduotoju - Virginijus Česnulevičius, štabo viršininku - Jonas Gečas, atsakingu už žvalgybą ir informaciją buvo paskirtas Alfonsas Bajoras, už tvarką rūmų viduje - Vitalijus Straleckas, už aprūpinimą - Algimantas Samajauskas, išorès rūmų gynybos organizavimas patikètas Gediminui Jurčiukoniui ir Vincui Viriukaičiui ${ }^{66}$.

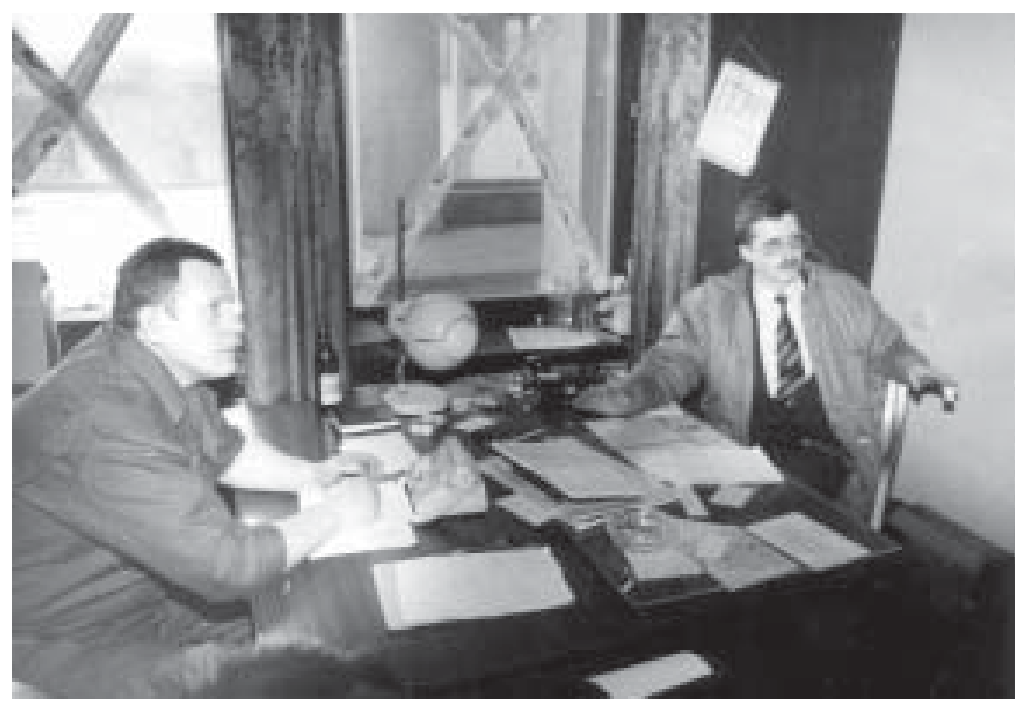

Česlovas Jezerskas ir Audrius Butkevičius $1991 \mathrm{~m}$. sausio dienomis Aukščiausiojoje Taryboje

Sigito Ruzo vadovaujami Afganistano kare dalyvavę vaikinai iš Kauno pradejo pirmuosius minavimo darbus. Buvo bandoma įtvirtinti ir pačius Aukščiausiosios Tarybos rūmus. Sausio $11 \mathrm{~d}$. ant rūmų stogo buvo pritvirtintos vokiškos prieštankinès granatos su elektroniniais de-

${ }^{66}$ Ten pat. 
tonatoriais, ruošiami degaus mišinio, vadinamojo „Molotovo kokteilio", buteliai ${ }^{67}$. Vidas Čepulis atgabeno kelias radijo stotis, su kuriomis ne tik buvo organizuota ryšio tarp štabo ir gynybiniu postų išoreje sistema, bet ir pradèta klausytis sovietiniu kariškiu pokalbių. Tai ypač pagerino rūmu gynèju padètį, nes suteikè galimybę geriau pasiruošti galimai atakai: iš anksto jau buvo žinoma apie karinių kolonų judejjimą.

Buvo atvežta keli šimtai dujokaukių. Jomis buvo aprūpinti ne tik rūmu gynejjai, bet ir Aukščiausiosios Tarybos deputatai. Buvo bandyta gauti kranų ir greideriu barikadoms statyti, tačiau tada nè viena statybos organizacija nesutiko ju duoti. Vincui Viriukaičiui buvo ịsakyta rengti autobusu, kuriais iš kitų miestų ir rajonų atvyko žmonès budèti prie Aukščiausiosios Tarybos, užtvaras.

M. Mažvydo bibliotekoje buvo ịkurtas Raudonojo Kryžiaus štabas. Atvežta tvarsliavos, neštuvu, vaistu, aikštėje nuolat budejo medikai, buvo sudaryta žmonių evakavimo iš rūmu prieigu schema, paskirti už tai atsakingi ${ }^{68}$. Buvo kaupiamos žinios apie rusu kariuomenès judejjimą. Ją iš esmès rinko patys rūmų gynejai, o duomenis daugiausia teikè netoli karinių daliniu gyvenantys žmonès ir kt.

Sausio 10 d. SSRS prezidentas M. Gorbačiovas paskelbė ultimatumą: „Lietuvos Respublikos Aukščiausiajai Tarybai tučtuojau visiškai atkurti SSRS Konstitucijos galiojimą, atšaukti anksčiau priimtus antikonstitucinius aktus". Gaunama vis daugiau informacijos apie kariuomenès daliniu judëjimą, "Jedinstvos" būriu veiksmus.

Sausio $11 \mathrm{~d}$. prasidèjo atvira agresija: užimami Spaudos rūmai, peršaunamas ju gynejjas Vytautas Lukšys, sužalojami keli žurnalistai. Užimant Krašto apsaugos departamento pastatą buvo sumušti grobikams pasipriešinę Klemensas Radzevičius, Jonas Paužolis ir kiti KAD darbuotojai. Vakare

${ }^{67}$ Krašto apsaugos savanorių pajëgos. - V., 2001. - P. 11.

${ }^{68}$ Gečas J. Viena praejjusio dešimtmečio savaite // Karys. - 2000. - Nr. 8. - P. 8. 
dviem lèktuvais TU-134A į Vilniu buvo atskraidinta KGB specialiosios paskirties grupe "Alfa"69.

Tomis dienomis tiek krašto apsaugos darbuotojai, tiek visi Lietuvos žmonės stojo ginti svarbiausių Lietuvos objektu - Aukščiausiosios Tarybos, Vyriausybès, Radijo ir televizijos centro, televizijos bokšto, Spaudos rūmų.

Prie Aukščiausiosios Tarybos rūmų budèjo tūkstančiai žmoniu, o viduje buvo susirinkę keli šimtai savanoriu parlamento gyneju. Sausio $11 \mathrm{~d}$. 14 val. jie prisiekè Tèvynei. Vyrus pasveikino Aukščiausiosios Tarybos Pirmininkas V. Landsbergis, KAD generalinis direktorius A. Butkevičius, palaimino kunigas R. Grigas. Po priesaikos vaikinai spaude vieni kitiems rankas, glèbesčiavosi, bučiavosi, atsisveikino kaip prieš tikrą mūši. Tada galbūt dar ne visi suvokè, kad tikrų tikriausias mūšis Vilniaus centre gali nugriaudèti po kelių valandų ${ }^{70}$.

Tomis tragiškomis sausio dienomis daugiausia savanorių buvo iš Krašto apsaugos departamento, pasieniečiuc. Tuo metu kitos realios ir masinès KAD struktūros ir nebuvo. Daugiau kaip 1000 pasieniečiu gynė Aukščiausiosios Tarybos, Vyriausybès rūmus, televizijos bokštą, Spaudos rūmus ir tuo pačiu metu budejo postuose. Aukščiausiają Tarybą gyne ir Aukščiausiosios Tarybos Apsaugos skyriaus darbuotojai, KAD zoninių skyrių pareigūnai, KAD Apsaugos tarnybos darbuotojai.

1991 m. sausio 11 d. Lietuvos Respublikos Aukščiausioji Taryba nusiuntė protesto notą Sovietų Sajungos vyriausybei. Tačiau SSRS reguliariosios ginkluotosios pajėgos sausio 11-12 d. toliau vykdè savo operacijas. Naudojant ginklą buvo užgrobiami bei niokojami valstybiniai objektai ir teisèsaugos įstaigos, blokuojami keliai, transportas, ryšiai.

Lietuvos Respublikos Aukščiausioji Taryba $1991 \mathrm{~m}$. sausio 12 d. šiuos SSRS veiksmus vertino kaip atvirą karinę agresiją ir pareikalavo nedelsiant ją nutraukti. Aukščiausioji

${ }^{69}$ Ten pat. - P. 8-9.

${ }^{70}$ Čekanauskas B. Stiprūs ne ginklais, o dvasia // Karys. - 1991. - Nr. 3. - P. 9-10. 
Taryba pavedè savo Prezidiumui kartu su Vyriausybe sudaryti Lietuvos Respublikos laikinają gynybos vadovybę. Jos sudètị ir statusą turejjo patvirtinti Aukščiausioji Taryba.

Tuo pačiu nutarimu Lietuvos Respublikos vidaus reikalu ir krašto apsaugos padaliniai gavo teisę priešintis svarbiausius valstybinius objektus užgrobti siekiančiam užpuolikui ${ }^{71}$.

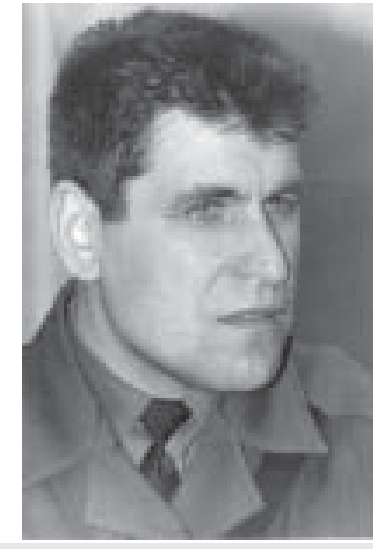

Jonas Gečas

Sausio 12 d. itampa pasiekè aukščiausią laipsnị. Ypač ji buvo jaučiama rūmų viduje. Visi suprato, kad puolimo metu tiems, kurie yra viduje, likti gyviems nedaug galimybiu. Kitas, kaip prisimena rūmų gynybos štabo viršininkas Jonas Gečas, ne mažiau svarbus klausimas, jaudinęs rūmu gynejjus, buvo - kada šauti? Bijota ne tik žūties - jai visi likusieji rūmuose po priesaikos buvo pasirengę, - bet galimos išdavystès ar klaidos. Šis klausimas ne kartą buvo aptariamas su vadais, nes dideliuose Aukščiausiosios Tarybos rūmuose buvo neįmanoma netikètos atakos metu sulaukti įsakymo iš štabo, kiekvieno gynybos posto vadas sprendimą, kuris galëjo būti lemtingas, turejjo priimti pats. Sis atsakomybès jausmas vertẻ būti įsitempusiems ir dar labiau didino nerimą.

Gynejai praktiškai buvo nemiegoję jau kelias paras. Nebuvo kur, o ir užmigti daugeliui buvo sunku ${ }^{72}$.

Sausio 13 d., tuoj po vidurnakčio, iš Šiaurès miestelio pajudèjo tankų kolona. Aukščiausiosios Tarybos rūmu gynejjai pasirengė kovai, tačiau kolona pasuko Vilniaus televizijos bokšto link.

\footnotetext{
${ }^{71}$ Dèl priemonių Lietuvos Respublikai ginti. Lietuvos Respublikos Aukščiausiosios Tarybos nutarimas // Lietuvos Respublikos Aukščiausiosios Tarybos ir Vyriausybės žinios. - 1991. - Nr. 3. - P. 97.

${ }^{72}$ Gečas J. Viena praejusio dešimtmečio savaite // Karys. - 2000. - Nr. 8. - P. 9.
} 
$1991 \mathrm{~m}$. sausio 13-osios nakti prie televizijos bokšto buvo pralietas kraujas. Tuo tarpu KAD vyrai, Aukščiausiosios Tarybos gynejjai, prisiekę ištikimybę Lietuvai, puikiai suprasdami, kad turimais ginklais negalès rimčiau pasipriešinti agresoriui, nepasitrauke iš Aukščiausiosios Tarybos rū$\mathrm{mu}$, nors galëjo... Tiesa, vienas kitas išèjo...

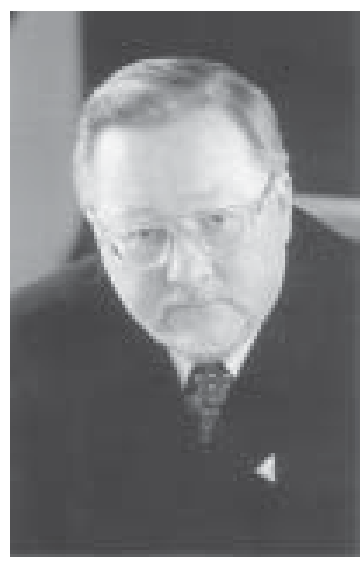

Vytautas Landsbergis

Gynëju ginklai buvo metaliniai strypai, peiliai, sportiniai mažo kalibro ir medžiokliniai šautuvai bei benzino buteliai, o pagrindinis ginklas - ryžtas ir noras apginti neseniai atgautą Nepriklausomybę ${ }^{73}$. Pagrindiniu ginklu teikèju tapo Lietuvos bankas. Iš banko sandèlių buvo paimti inkasatorių ginklai, dalis ginklu įsigyta medžiotoju parduotuvèse, nemažai jų atsineše patys gynëjai.

Sausio $13 \mathrm{~d}$. buvo sudaryta Lietuvos Respublikos laikinoji gynybos vadovybè, į kurią įejo: V. Landsbergis, A. Šimėnas, A. Butkevičius, Z. Vaišvila, V. Zabarauskas, M. Laurinkus, R. Ozolas, A. Abišala. Aukščiausioji Taryba įpareigojo Laikinają gynybos vadovybę vadovauti fizinès (karinès), politinès, informacinès ir kitokios gynybos veiksmams, kol SSRS puolimas ir karas prieš Lietuvą bus nutrauktas. Ji taip pat buvo ipareigota sudaryti Lietuvos Respublikos gynimo bei koordinavimo grupes ${ }^{74}$.

1991 m. sausio 17 d. buvo ịkurta Savanoriškoji krašto apsaugos tarnyba (SKAT). Aukščiausiosios Tarybos rūmų apsaugos štabas faktiškai tapo ir SKAT štabu. I SKAT pirmiausia įstojo Aukščiausiają Tarybą saugoję vyrai.

\footnotetext{
${ }^{73}$ Pocius A. Trečioji savanorių karta // Konferencijos „Lietuvos krašto apsaugos sistemos atkūrimas“ medžiaga. - P. 85.

${ }^{74}$ Dèl Lietuvos Respublikos laikinosios gynybos vadovybès sudarymo. Lietuvos Respublikos Aukščiausiosios Tarybos nutarimas // Lietuvos Respublikos Aukščiausiosios Tarybos ir Vyriausybès žinios. - 1991. - Nr. 3. - P. 98.
} 
İkūrus Savanoriškają krašto apsaugos tarnybą, tiksliau juridiškai įteisinus savanorių veiklą, buvo išspręstas dar vienas svarbus uždavinys - $i$ valstybès gynimą oficialiai buvo įtraukta visuomenè, kuri galëjo ginti valstybę jau remdamasi įstatymu.

Tačiau reikia pažymèti, kad SKAT ịkurti paskatino ne sausio įvykiai. Jie tik paspartino Savanoriškosios krašto apsaugos tarnybos įstatymo prièmimą. İstatymo projektas buvo parengtas $1990 \mathrm{~m}$. lapkričio mènesi, nes nuo pat pirmuju Krašto apsaugos departamento veiklos dienu buvo planuojama kurti Lietuvos kariuomenę kaip nacionalinę gvardiją, todèl savanoriu padaliniu pagrindas buvo sukurtas dar iki priimant įstatymą. Neoficialiai jau veikè savanorių rinktinès, kuopos, būriai, kurie, prièmus įstatymą, buvo oficialiai įteisinti. Savanoriu rinktinès Vilniuje, Kaune ir Klaipedoje jau èmė veikti 1990 metu vasarą ${ }^{75}$.

Pagrindinis tikslas, kuris buvo iškeltas Savanoriškajai krašto apsaugos tarnybai, - rengti Lietuvos Respublikos piliečius Tèvynès gynybai, stiprinti Krašto apsaugos sistemos pajègas.

Savanoriškoji krašto apsaugos tarnyba buvo tiesiogiai pavaldi KAD generaliniam direktoriui, kuriai jis vadovavo per KAD generalinio direktoriaus pavaduotoją Savanoriškajai krašto apsaugos tarnybai ir Savanorių tarnybos štabą.

1991 m. sausio 23 d. Savanoriškosios krašto apsaugos tarnybos štabo viršininku buvo paskirtas Jonas Gečas ${ }^{76}$.

Laikinoji SKAT struktūra - štabas, štabo operatyvinis būrys, SKAT mokykla, 8 rinktinés ir 100 kuopu - ir etatai oficialiai buvo patvirtinti $1991 \mathrm{~m}$. kovo $1 \mathrm{~d}$.

\footnotetext{
${ }^{75}$ Pocius A. Trečioji savanorių karta // Konferencijos „Lietuvos krašto apsaugos sistemos atkūrimas“" medžiaga. - P. 83.

${ }^{76}$ Norkus C. Tẻvynès labui. - P. 188.
} 


\section{Departamento plètra po $1991 \mathrm{~m}$. sausio ivykiuc}

Po sausio įvykiu grèsmė Aukščiausiajai Tarybai ir Vyriausybei nesumažèjo. SSRS kariškiai galejjo bet kuriuo momentu atnaujinti puolimą. Jaunai KAD žvalgybos tarnybai pavyko gauti SSRS kariškiu parengtus naujos, daug grèsmingesnès ir geriau apgalvotos agresijos prieš Lietuvos nepriklausomybę planus. Todèl reikejjo rimtai ruoštis.

$1991 \mathrm{~m}$. sausio 29 d. A. Butkevičius kreipèsi į Vyriausybę, siūlydamas įsteigti Garbės sargybos kuopą ${ }^{77}$. Gavus sutikimą, vasario $2 \mathrm{~d}$. į šią kuopą buvo atrinkti žmonès ${ }^{78}$.

1991 m. vasario 22 d., sujungus Atskirąą apsaugos ir Garbès sargybos kuopas, buvo įkurtas Mokomasis junginys ${ }^{79}$, 300 savanoriu profesionalu grupè, tapusi būsimos Lietuvos sausumos kariuomenès pagrindu. Jo vadu buvo paskirtas Česlovas Jezerskas, štabo viršininku - L. Paužolis, I kuopos va$\mathrm{du}-\mathrm{R}$. Baltušis, II kuopos vadu - P. Kasteckas. Junginiui buvo iškeltas uždavinys - būsimai Lietuvos kariuomenei rengti puskarininkius.

Buvo numatyta, kad tarnavusieji sovietinëje kariuomenëje puskarininkio laipsni gaus po pusès metu, netarnavusieji

\footnotetext{
${ }^{77}$ A. Butkevičiaus 1991 m. sausio 29 d. raštas Lietuvos Respublikos Vyriausybei // KAA.- F. 1. - Ap. 1. - B. 20.- L. 27.

${ }^{78}$ I Garbès sargybos kuopą buvo priimti: A. Sirtautas - kuopininku, A. Belkis, J. Kovalevskis, A. Krasilnikovas, A. Volkovas, E. Žentelis, K. Bepirštis, A. Vaitkevičius, D. Pašukonis, E. Tukal, S. Juozaitis, A. Baltutis, M. Jamkūnas, R. Augustinavičius, S. Kaušas, A. Biliūnas, K. Treigys, V. Raginskas, A. Stacevičius, R. Cvirka, A. Venckūnas, R. Nepas, R. Stankevičius, V. Briedis, S. Botyrius, V. Kulevičius, V. Žilakauskas, R. Klerovskis, P. Kapustinskas, Ž. Stirna, V. Druteika, A. Gžimaila, G. Želna, R. Žubrickas, A. Žentelis, R. Jefremovas, V. Bublys, A. Nerkus, K. Bakutis, V. Zupka, D. Mačiulis, A. Alionis, A. Morauskas, G. Apulskis, A. Stecevič, J. Aleknavičius, E. Pernaravičius, V. Steiblys, D. Grušas, L. Misevičius, E. Popovas, R. Vaitkevičius, G. Jonikas, A. Jurgaitis, R. Abarius, D. Vaivara, E. Glavdel, J. Valiukynas, R. Vingeris, V. Kastlovskis, R. Vaikšnora, V. Dabkus, V. Griškevičius, S. Zoruba, E. Šaltis, J. Sadauskas, R. Baltrūnas, P. Mackonis, M. Veršilovičius, A. Daukšta, D. Matulis, V. Stravinskas, R. Gudaitis - šauliais // Dèl žmonių prièmimo ị Garbės kuopą. Atskirosios kuopos vado 1991 m. vasario 2 d. įsakymas Nr. 2 // KAMEA. - F. 1.- Ap. 2.- B. 117. - L. 2 a. p.

${ }^{79}$ A. Butkevičiaus 1991 m. sausio 29 d. raštas Lietuvos Respublikos Vyriausybei // KAA. - F. 1. - Ap. 1.- B. 20. - L. 27.
} 
- po metų. Baigusieji Mokomojo junginio kursą galès laikyti egzaminus karininko laipsniui gauti. Mokomasis junginys buvo komplektuojamas savanoriškumo principu. Norinčiujų buvo kur kas daugiau, negu vietu, todẻl teko atlikti griežtą atranką. Iš pradžių junginys įsikūrè Vilniuje, Gynejju gatvëje.

Mokomojo junginio kariai buvo mokomi statutu, taktikos, topografijos, radijo ryšio organizavimo pagrindu, artimosios kovos veiksmu (karatè, sambo, dziudo, bokso), suteikti pirmąją medicinos pagalbą. Kasdien po kelis kartus vyko rikiuotès pratybos. Daliniui buvo išduotos naujos žalios spalvos karinès uniformos.

Krūvis buvo nemažas. Diena prasidèdavo 7 val. ir baigdavosi 22 val., todèl jau gana greitai silpnesni kariai dalini paliko, apie 20 buvo atleisti dèl drausmès pažeidimų.

Be pratybu, kuriose turejjo dalyvauti, Mokomojo junginio kariai budejjo Aukščiausiosios Tarybos, Ministrų Tarybos rūmuose, banke, patruliavo Vilniuje ir Kaune ${ }^{80}$.

Junginys Aukščiausiosios Tarybos, Vyriausybės ir buvusiuose Profsajungu rūmuose išstatè nuolatinius sargybos postus. Visą parą prie Aukščiausiosios Tarybos ir Vyriausybės rūmų buvo patruliuojama, grupe karių, kurie visą laiką buvo kovinès parengties, nuolat stebejo Aukščiausiosios Tarybos ir Vyriausybès rūmu prieigas. Reikia pažymèti, kad analogišką darbą dirbo ir SKAT vyrai ${ }^{81}$.

Nuo šiol KAD Mokomojo junginio bei SKAT vyrai rūpinosi nuolatine Aukščiausiosios Tarybos ir Vyriausybès rūmų apsauga.

1991 m. pavasari KAD Informacijos skyrius reorganizuojamas į Informacijos tarnybą. Joje buvo įkurtas A skyrius, kuris perėmé žvalgybos funkcijas. Skyrius toliau rinko informaciją apie sovietinę armiją, pradèta informaciją analizuoti,

\footnotetext{
${ }^{80}$ Vèl ruošiami puskarininkiai // Karys. - 1991. - Nr. 4. - P. 2.

${ }^{81}$ Dèl Lietuvos Respublikos Aukščiausiosios Tarybos ir Lietuvos Respublikos Vyriausybès rūmų apsaugos. KAD $1991 \mathrm{~m}$. kovo 14 d. įsakymas Nr. 29 // Krašto apsaugos departamento generalinio direktoriaus ir krašto apsaugos ministro ịsakymų rinkinys. 1991 m. - P. 23-25.
} 
vykdoma kontrpropaganda, platinami atsišaukimai tarp sovietinių kariškių ${ }^{82}$.

1991 m. sausio įvykiai parodè, kad prieš brutalią sovietų kariaunos jègą galima atsilaikyti tik taikiai priešinantis, susitelkus ir esant vieningiems, nesudarant priešininkui dingsties panaudoti ginklą arba tai pateisinti "objektyviu būtinumu“.

Kad iš anksto būtų pasirengta duoti atkirtį naujiems galimiems sovietinès kariaunos veiksmams, siekiant neutralizuoti jų ir specialiuju tarnybų organizuotą prievartos ir dezinformacijos kampaniją, Krašto apsaugos departamentas atkreipe dèmesi i i psichologinę gynybą: pradèta formuoti Psichologinės gynybos grupè. $1991 \mathrm{~m}$. vasario $1 \mathrm{~d}$. KAD generalinis direktorius A. Butkevičius jau galëjo pasiūlyti Lietuvos Respublikos valstybinès derybu su SSRS delegacijos nariams praktiniams derybu igūdžiams įgyti KAD Psichologinès gynybos grupès parengtą mokymo programą.

Vasario viduryje buvo nuspręsta Psichologinès gynybos grupès veiklą išplèsti ir šiai problemai skirti dar daugiau dèmesio. Vasario 20 d. A. Butkevičius įsakẻ įsteigti Krašto apsaugos departamento Psichologinés gynybos ir pilietinio pasipriešinimo komisiją. Komisijos vadove buvo paskirta filosofijos mokslų kandidatė Gražina Miniotaitè. Tuo pačiu įsakymu komisijos vadovė iki kovo $12 \mathrm{~d}$. buvo ịpareigota parengti neprievartinio pasipriešinimo instrukciją, skirtą KAD etatiniams darbuotojams ir Savanoriškosios krašto apsaugos tarnybos savanoriams, iki vasario $28 \mathrm{~d}$. - komisijos darbo programą, kartu su Vilniaus universiteto Sociologiniu tyrimu laboratorija - komisijos veiklai organizuoti reikalingą sociologiniu tyrimu programą, kartu su Valstybine komisija Rytu Lietuvos problemoms išnagrinèti ir rengti šio regiono integravimosi Lietuvos Respublikoje programas.

Savanoriškosios krašto apsaugos tarnybos štabo viršininkas buvo ịpareigotas teikti komisijai reikalingą pagalbą, organizuoti savanorių mokymą pagal neprievartinio pa-

${ }^{82}$ Yra tokia tarnyba // Karys. - 1998. - Nr. 42/-. P. 3. 
sipriešinimo programas. Komisijos darbui reikiamas lëšas nuspręsta skirti iš Gynybos fondo ${ }^{83}$.

Tokios komisijos įkūrimo ideją parèmè ir Lietuvos Respublikos Vyriausybė. 1991 m. vasario 26 d. Ministro Pirmininko G. Vagnoriaus pasirašytu potvarkiu buvo įsteigta KAD Psichologinès gynybos ir pilietinio pasipriešinimo komisija. KAD generaliniam direktoriui buvo pavesta patvirtinti nurodytosios komisijos sudetir ${ }^{84}$.

Iš pradžiu buvo pradèta rengti medžiaga "Gimtajam kraštui“" su rubrika „Perskaityk, išsikirpk ir perduok kitam”. Ten buvo aprašomas kitų šaliu patyrimas ir pateikiami įrodymai, jog tokia gynyba yra galima, kad ji turi savo metodus, tikslus ir t. t., kad į kiekvieną grèsmingą užpuolimą galima atsakyti ne smurtu. Kolaborantus galima demaskuoti ir išvaryti, pastatus masinemis akcijomis gali apginti ir sugrąžinti neginkluoti žmonès. Taip pat teigiama, kad pavieniai nesmurtiniai pasipriešinimo veiksmai, jei jie sudarys nesmurtinę kampaniją, virs galinga jèga.

Kiek vèliau į šią komisiją buvo pakviesti 5 specialistai iš JAV, kurie su šiomis idėjomis supažindino savanorius, Sajūdžio žmones, skaitė paskaitas visuomenei.

Balandžio 24-gegužès $1 \mathrm{~d}$. KAD kvietimu Lietuvoje viešejo JAV Alberto Einšteino instituto vadovas Gene Šarpas (Sharp) - vienas žymiausių nesmurtinio pasipriešinimo ir psichologinès gynybos specialistu, jo mokslinis asistentas Briusas Dženkinsas (Bruce Jenkins) bei Londone dirbantis instituto mokslinis bendradarbis Peteris Ackermanas (Peter Ackerman) ${ }^{85}$.

Kitas komisijos uždavinys buvo teikti teisingą informaciją apie Lietuvą kitoms šalims. Tai buvo savotiška kontrpropaganda.

\footnotetext{
${ }^{83}$ Dèl Krašto apsaugos departamento Psichologinès gynybos ir pilietinio pasipriešinimo komisijos įsteigimo ir darbo organizavimo. KAD $1991 \mathrm{~m}$. vasario 20 d. ịsakymas Nr. 12 // Krašto apsaugos departamento generalinio direktoriaus ir krašto apsaugos ministro įsakymų rinkinys. 1991 m. - P. 5-6.

${ }^{84}$ Lietuvos Respublikos Vyriausybès $1991 \mathrm{~m}$. vasario 26 d. potvarkis // KAM EA.

${ }^{85}$ Krašto apsaugos departamento kronika // Karys. - 1991. - Nr. 6. - P. 42.
} 
Tačiau ši komisija dirbo neilgai. 1991 m. gegužès mènesį Krašto apsaugos departamente buvo įkurtas Informacinės gynybos skyrius, kuris tęse komisijos pradètą darbą.

Nors ir pamokyti per sausio įvykius, sovietiniai kariškiai, Vilniaus ir Rygos OMON'o grupuotès bei kai kurie privatūs asmenys pradejjo agresyvius veiksmus prieš Lietuvos pasieniečius bei muitininkus. $1991 \mathrm{~m}$. sausio-vasario mėn. nuostoliu patyrè Vilniaus, Šalčininku, Ignalinos, Pakruojo, Skuodo ir Varėnos-Druskininkų užkardos, gegužès-birželio mèn. - Vilniaus, Šalčininku, Mažeikiu, Biržu, Pasvalio, Joniškio, Akmenės, Zarasu, Varėnos-Druskininkų užkardos ir Kalvarijos kontrolès postas. Bendra visų nuostolių suma siekè 207 274, 32 rublio.

Buvo puldinejjami ne tik pasienio apsaugos postai, bet ir muitinès. Per tą patị laikotarpi muitinèms padaryta 182, 9 tūkst. rublių nuostolių ${ }^{86}$.

Nuo 1991 m. sausio iki pučo Maskvoje žlugimo dienos SSRS kariuomenės ir OMON'o užpuolimo metu buvo sužaloti šie Pasienio apsaugos tarnybos pareigūnai:

Pasvalio užkardoje - G. Adikelis, A. Arsimavičius, A. Gudas, R. Gutauskas, A. Remeika, A. Valeika;

Biržų užkardoje - V. Fenderis, D. Kaulinis;

Kalvarijos užkardoje - V. Grabauskas, S. Paliulis, E. Pranskevičius, S. Žemaitis;

Zarasu užkardoje - V. Barkauskas, S. Bučinskas, A. Guobys, A. Švilpa;

Šalčininkų užkardoje - A. Bandza, G. Dapkus, M. Muraška, F. Petkus, P.Pumputis;

Vilniaus rajono užkardoje - J. Kazlauskas, P. Slavinskas, G. Vaškelis, V. Voveris, G. Žukaitis;

Vilniaus miesto užkardoje - T. Lietuvininkas;

Akmenés užkardoje - R. Adomaitis, V. Baltrušaitis, V. Bložè, A. Butkus, Ž. Statkus, J. Suchorevskis, V. Šim-

${ }^{86} 1991$ m. birželio 24 d. KAD apsaugos tarnybos pažyma apie padarytus materialinius nuostolius // KAMEA (byla nenumeruota). 
kus, S. Žičkus ${ }^{87}$.

Valstybès sienu apsauga nepatiko ir tiems Lietuvos piliečiams, kurie, pasinaudodami sunkia ekonomine šalies padètimi, iš Lietuvos neteisėtai išveždavo prekes. Mašinu, kurios bandydavo išvežti uždraustas prekes, vairuotojai paprastai stabdomi nestodavo, o padidindavo greiti, tuo sukeldami pavoju pasienio apsaugos darbuotojams. Atsižvelgiant i tai visuose pasienio kontrolès postuose buvo įrengtos dirbtinès pervažiuojamosios kliūtys ${ }^{88}$.

Be viso to, buvo ir kitu rimtu problemų. $1991 \mathrm{~m}$. sausio $30 \mathrm{~d}$. KAD generalinis direktorius informavo Lietuvos $\mathrm{Vy}-$ riausybę, kad dar nèra bendros formos leidimu prekèms už Lietuvos ribų išvežti. Pasienio apsaugos pareigūnai neturèjo teisės surašyti administracinès teisės pažeidimu protokolu, sulaikę neteisėtai išvežamas prekes, 22 postuose nebuvo muitiniu, kai kur iki artimiausių muitiniu buvo $50-70 \mathrm{~km}$. Nebuvo išspręsti ir sulaikytų prekių įvertinimo, jų realizavimo ir laikymo klausimai. Ne darbo ir švenčių dienomis prekių žinovai ir liaudies teismai nedirbo. Be to, KAD pasienio postuose budejo tik po 4 beginklius pareigūnus.

Sieną saugoti buvo ypač sudėtinga Šalčininku rajone. Jame nuolat buvo rengiamos provokacijos bei grasinama fiziškai sunaikinti KAD Pasienio apsaugos tarnybos skyriaus postus ir pareigūnus. Esant tokiai padéčiai, Pasienio apsaugos tarnybos viršininkas V. Česnulevičius kreipési į vidaus reikalų ministrą $M$. Misiukonį, prašydamas pasieniečiams paramos - skirti policininkus ${ }^{89}$. Tačiau Policijos departamentas neturejo galimybiu skirti policijos pareigūnų, kurie nuolat budètų pasienio užkardose. Šalčininkų rajono policijos komisariatui buvo tik pavesta operatyviai reaguoti i teisètvarkos pažeidimus ar provokaci-

\footnotetext{
${ }^{87}$ Pažyma apie $1991 \mathrm{~m}$. SSRS kariuomenès ir OMON'o užpuolimų metu sužalotus Pasienio apsaugos tarnybos pareigūnus // KAMEA (byla nenumeruota).

${ }^{88}$ Dèl dirbtinių pravažiavimo kliūčių ịrengimo. $1990 \mathrm{~m}$. gruodžio 27 d. KAD generalinio direktoriaus aplinkraštis // Ten pat.

${ }^{89} 1991$ m. kovo 27 d. V. Česnulevičiaus raštas M. Misiukoniui // Ten pat.
} 
jas pasienio postuose ${ }^{90}$.

$1991 \mathrm{~m}$. birželio 6 d. KAD generalinio direktoriaus įsakymu „Dẻl departamento struktūrų ir etatų pakeitimo“ buvo panaikintas Pasienio apsaugos tarnybos skyrius ir sukurta Pasienio apsaugos tarnyba.

Nuo $1991 \mathrm{~m}$. birželio $15 \mathrm{~d}$. buvo pakeista budèjimo pasienyje tvarka. Pagal naujai patvirtintus etatus nebuvo numatyta skirstymo i patrulius ir posto budètojus, nesudaroma nuolatinių budėtojų pamainų. Visi užkardos pareigūnai turèjo gerai pažinti užkardai priskirto pasienio ruožo teritoriją?

Nuo 1991 m. liepos 15 d. kiekvienoje užkardoje buvo įkurtos 10-15 asmenu operatyvinès grupès. I grupes buvo atrenkami gerai fiziškai ir psichologiškai pasirengę pareigūnai, ypatingą dèmesį kreipiant ị mokẻjimą naudotis ginklu. Šios grupés buvo papildomai mokomos, treniruojamos ${ }^{92}$.

$1991 \mathrm{~m}$. liepos 31 d., tarp 3 ir 5 val. ryto, Medininku pasienio apsaugos poste buvo žvèriškai nužudyti šeši ir sunkiai sužeisti du pareigūnai, kurie vykdè savo pareigas - saugojo Lietuvos Respublikos sieną.

Šios tragedijos bei ankstesniu pasienio apsaugos postų užpuldinejjimai, kurių metu buvo smurtaujama, tyčiojamasi iš Pasienio apsaugos tarnybos pareigūnuc plèšikaujama, analizè rodè, kad nebaudžiamas pasienio apsaugos postų užpuldinèjimas ir jų niokojimas yra galimas tik dèl to, jog Pasienio apsaugos tarnybos pareigūnai yra neginkluoti, organizuota tarnyba nepakankamai budri, o patys postai tarnybai neparengti. Atsižvelgdama ic tai, $1991 \mathrm{~m}$. liepos $31 \mathrm{~d}$. Lietuvos Vyriausybė įvedè sugriežtintą pasienio kontrolès režimą. Šiuo potvarkiu Krašto apsaugos departamentas buvo įpareigotas užtikrinti asmenų ir transporto priemonių dokumentų tikrinimą bei registravimą. Buvo leista pareig $\bar{u}-$

\footnotetext{
${ }^{90} 1991$ m. balandžio 8 d. generalinio komisaro P. Liuberto raštas Krašto apsaugos departamentui // Ten pat.

${ }^{91} 1991$ m. balandžio 5 d. PAT skyriaus viršininko V. Česnulevičiaus raštas užkardų viršininkams // Ten pat.

${ }_{92} 1991$ m. liepos 4 d. PAT viršininko V. Česnulevičiaus raštas užkardų viršininkams // Ten pat.
} 
nams, vykdantiems pavedimus ypač pavojingomis sąlygomis, atlyginimą per ménesi padidinti tris kartus ${ }^{93}$.

Vykdydamas ši Vyriausybės potvarkị, rugpjūčio $2 \mathrm{~d}$.

KAD generalinis direktorius įsakè apginkluoti Pasienio apsaugos tarnybos pareigūnus šaunamaisiais ginklais ir specialiosiomis priemonemis, panaudoti asmeninius lygiavamzdžius šautuvus bei šaunamuosius ginklus, įsigytus už Gynybos fondo lèšas.

Tačiau šios nutarimo dalies vykdymą $1991 \mathrm{~m}$. rugpjūčio 7 d. potvarkiu vicepremjeras V. Pakalniškis, motyvuodamas tuo, kad tai prieštarauja Lietuvos Respublikos Vyriausybės $1991 \mathrm{~m}$. gegužès $24 \mathrm{~d}$. nutarimui, kuriame nurodoma, jog šaunamieji ginklai Krašto apsaugos tarnybos darbuotojams išduodami tik pagal Lietuvos Respublikos Vyriausybės sprendimą, sustabdè. Jis Krašto apsaugos departamentą ipareigojo imtis visų būtinų priemoniu, kad būtų pasirengta prireikus išduoti pasienio apsaugos pareigūnams ginklus laikantis Lietuvos Respublikos įstatymų ir Lietuvos Respublikos normatyvinių aktų nustatytos tvarkos.

1991 m. sausio 30 d. Ministras Pirmininkas, remdamasis Lietuvos Respublikos krašto apsaugos tarnybos įstatymo 37 straipsniu, savo potvarkiu leido karininkams, tarnaujantiems Krašto apsaugos departamente, suteikti anksčiau turètus karinius laipsnius ir įskaityti į tarnybos stažą tarnybos laiką kitų šalių kariuomenėse ${ }^{94}$.

Reikia pažymèti, kad SSRS karinè vadovybè panaikino pradẻjusių dirbti Krašto apsaugos departamente atsargos karininku laipsnius: pulkininko-A. S. Kairio, A. Pakalkos, B. Vizbaro, R. Bajoro, A. Vaitkaičio, papulkininkio - C.Norkaus, Z. P. Orento, V. J. Kadžio, R. Dubicko, N. Kovtuno, A. Šerelio, J. A. Paužolio, E. Musteikio, majoro - B. A. Genžinsko, J. S. Borisevičiaus, L.Gregubo, A. G. Valinčiaus, J. Silevi-

\footnotetext{
${ }^{93}$ Dèl sugriežtinto pasienio kontrolès režimo įvedimo. Lietuvos Respublikos Vyriausybès 1991 m. liepos 31 d. potvarkis Nr. 493p.

${ }^{94}$ Dél Krašto apsaugos departamento sistemos darbuotojų - savanorių karinių laipsnių suteikimo. Lietuvos Respublikos Vyriausybès $1991 \mathrm{~m}$. sausio 30 d. potvarkis Nr. 21p.
} 
čiaus, A. Aglinsko, V. E. Pliaterio, kapitono -A.Miliavičiaus, ir panaikino karininku pensijas ${ }^{95}$.

I Lietuvos karo tarnybą stojo ne tik karininkai, metę tarnybą SSRS ginkluotosiose pajègose, bet ir buvę SSRS atsargos karininkai, taip pat asmenys, neturintys jokiu kariniu laipsnių ir karinio pasirengimo. Iškilo būtinybè apibrèžti, kas yra karinis išsimokslinimas, kam gali būti suteikti kariniai laipsniai, patikslinti laipsniu suteikimo tvarką. Ši problema buvo aptarta $1991 \mathrm{~m}$. liepos $10 \mathrm{~d}$. KAD kolegijos posèdyje. Kolegijos posėdžiui buvo pateiktas svarstyti Lietuvos kariuomenès laipsnių suteikimo projektas. Kolegija po šiokių tokiu pataisymu jam pritare $\dot{e}^{96}$.

Deja, reikia konstatuoti, kad krašto apsaugos sistema nebuvo izoliuota nuo visuomenės, nuo joje vykstančiu negatyviu procesų. Neigiami reiškiniai, suvešèję visuomenëje, neaplenkè ir krašto apsaugos sistemos. Siekiant, kad Krašto apsaugos departamento sistemoje būtų ištiriami visi ypatingi atvejai, $1991 \mathrm{~m}$. balandžio $3 \mathrm{~d}$. buvo sudaryta nuolatinè komisija. I ją buvo paskirtas KAD I skyriaus viršininkas A. Dulevičius (pirmininkas) ir 3 nariai: juriskonsultas V. Valikonis, vyr. instruktorius pasienio režimui E. Leščinskas ir Kadrų skyriaus I kategorijos inspektorius R. Mačènas. Komisija buvo ịpareigota per 7 dienas KAD generaliniam direktoriui pateikti tyrimų išvadas dèl visų nelaimingu atsitikimu, nusikaltimų ar kitu ypatingu atveju, kuriuose dalyvavo Krašto apsaugos departamento ar jam pavaldžiu struktūrų darbuotojai ${ }^{97}$.

Buvo dar viena problema - nebuvo socialiniu garantiju įstatymo. Krašto apsaugos departamento darbuotojai, dirbdami ekstremaliomis sąlygomis, neturejjo jokių valstybès garantiju, kad, tarnybos metu atsitikus nelaimei, jais ir jų šeimo-

\footnotetext{
${ }^{95}$ Atsargos karininkų, kuriems atimti kariniai laipsniai ir pensijos, sąrašas // KAMEA (byla nenumeruota).

${ }^{96} \mathrm{KAD}$ kolegijos $1991 \mathrm{~m}$. liepos 10 d. posėdžio protokolas Nr. 10 // Ten pat.

${ }^{97}$ Dèl komisijos sudarymo ypatingiems atvejams tirti. KAD $1991 \mathrm{~m}$. balandžio 3 d. ịsakymas Nr. 37 // Krašto apsaugos departamento generalinio direktoriaus ir krašto apsaugos ministro įsakymų rinkinys. 1991 m. - P. 26.
} 
mis ims rūpintis valstybè. Pagaliau tai, kad tokio įstatymo nebuvo, priešino policijos ir krašto apsaugos pareigūnus, nes policininkams visos socialinés garantijos buvo užtikrintos.

$1991 \mathrm{~m}$. balandžio $11 \mathrm{~d}$. buvo sudaryta komisija Lietuvos Respublikos krašto apsaugos socialiniu garantiju įstatymui rengti. Komisijos pirmininku buvo paskirtas KAD generalinio direktoriaus pirmasis pavaduotojas A. Vaitkaitis, nariais - A. Dulevičius, A. Kairys, Ž. Braziulis, A. Pakalka, A. Bajoras, V. Žukas, F. Žinienè, Š. Vasiliauskas, A. Valikonis, V. Česnulevičius. Komisija įstatymo projektą turëjo parengti iki $1991 \mathrm{~m}$. balandžio $29 \mathrm{~d} .{ }^{98}$ Tačiau, nors projektas buvo parengtas, jo prièmimo Aukščiausiojoje Taryboje procedūra labai užtruko.

Krašto apsaugos departamentui augant, daugejjant jam keliamų užduočiu, departamento struktūra ir etatai ėmè nebeatitikti reikalavimu. 1991 m. gegužès 20 d. Lietuvos Respublikos Vyriausybė nutare pakeisti Krašto apsaugos departamento struktūrą ir etatus. Vykdant šį nutarimą, $1991 \mathrm{~m}$. birželio $6 \mathrm{~d}$. išleistame KAD įsakyme buvo nurodyta nuo birželio 1 d. panaikinti esamą KAD struktūrą ir etatus ir įvesti 1991 m. gegužès $21 \mathrm{~d}$. patvirtintą laikinąją struktūrą ir etatus.

Buvo patvirtinta pirmoji Krašto apsaugos departamento štabo laikinoji struktūra ir etatai. Štabe buvo įsteigti Operatyvinis, Žvalgybos, Mobilizacinis, Ryšiu, Inžinerinis-techninis, Specialiosios paskirties, Administracinis-ūkio skyriai bei štabo padalinys - Štabo komendantinè kuopa, susidedanti iš Vidaus ir Išorès apsaugos tarnybos būrių ${ }^{99}$.

Štabas liko pavaldus Krašto apsaugos departamento generaliniam direktoriui, o jam buvo pavaldžios apskričiu komendantūros ${ }^{100}$.

\footnotetext{
${ }^{98} \mathrm{KAD}$ generalinio direktoriaus $1991 \mathrm{~m}$. balandžio 11 d. įsakymas Nr. 41 // Ten pat. - P. 2728.

${ }^{99}$ Jurgaitis A. Krašto apsaugos ministerijos Gynybos štabo atkūrimas, jo raida // Konferencijos „Lietuvos krašto apsaugos sistemos atkūrimas“ medžiaga. - P. 66.

${ }^{100}$ Ten pat. - P. 67.
} 
Nuo 1991 m. birželio 1 d. èmé veikti KAD Imuniteto tarnyba. Jos svarbiausias uždavinys buvo rinkti visą KAD vadovybei reikalingą informaciją ${ }^{101}$.

$1991 \mathrm{~m}$. birželio $1 \mathrm{~d}$. buvo ikurta Mokomojo junginio Kauno kuopa. Kuopos vadu paskirtas Arvydas Raižys, būrių vadais - Valdas Kerulis ir Virgilijus Kisielius, būrininkais - Vladas Dobrovolskis ir Artūras Katilius, skyrininkais - V. Gelūnas, B.Aleknavičius, R. Greliauskas, S. Dumskis, K. Bilskis ir E. Žemaitis ${ }^{102}$.

Kiek vẻliau buvo įkurta Panevėžio kuopa.

$1991 \mathrm{~m}$. birželio 6 d. buvo suformuota ekspertų taryba Lietuvos karo laivynui atkurti. Jos vadovo pareigas prisièmé KAD generalinis direktorius A. Butkevičius, nariais buvo paskirti E. Miliauskas, J. Leišis, V. Urbas, V. Sirevičius. Tarybos uždavinys buvo suburti karo laivyno specialistus lietuvius, numatyti būsimojo karo laivyno struktūrą ir pasiruošti perimti iš sovietų kariuomenès Lietuvoje esančius karinius jūru objektus.

Siekiant padidinti Krašto apsaugos departamento valdymo operatyvumą, $1991 \mathrm{~m}$. birželio $12 \mathrm{~d}$. generalinis direktorius įsake tais atvejais, kai jo nèra, jo funkcijas operatyviais vadovavimo padaliniams ir tarnyboms klausimais vykdyti budinčiam generalinio direktoriaus pavaduotojui.

Operatyvinis budètojas turëjo žinoti generalinio direktoriaus ir budinčio pavaduotojo buvimo vietą ${ }^{103}$.

Atsižvelgiant į naują Krašto apsaugos departamento struktūrą ir patvirtintus etatus iki Lietuvos Respublikos Vyriausybės sprendimo nuo $1991 \mathrm{~m}$. birželio $1 \mathrm{~d}$. KAD generalinio direktoriaus įsakymu buvo paskirti generalinio direktoriaus pavaduotojai:

\footnotetext{
${ }^{101}$ A. Butkevičiaus 1991 m. rugpjūčio 2 d. raštas Ministrui Pirmininkui G.Vagnoriui // KAMEA. - F. 1. - Ap. 1. - B. 24. - L. 62.

${ }^{102}$ Dèl patvirtinimo. Dèl Mokomojo junginio. 1991 m. birželio 1 d. ịsakymas Nr. 228-K // KAMEA. - F. 1. - Ap. 2. - B. 117. - L. 84.

${ }^{103} \mathrm{KAD} 1991 \mathrm{~m}$. birželio 12 d. įsakymas Nr.70 // Krašto apsaugos departamento generalinio direktoriaus ir krašto apsaugos ministro įsakymų rinkinys. 1991 m. - P. 44.
} 
Norbertas Vidrinskas - pavaduotoju, Vyriausiojo štabo viršininku;

Jonas Paužolis - pavaduotoju mokymo ir kadrų klausimais;

Ignas Stankovičius - pavaduotoju informacijai ${ }^{104}$.

1991 m. birželio mėn. buvo likviduota Apsaugos tarnyba. Ji buvo perduota Savanoriškosios krašto apsaugos tarnybos štabo viršininkui. SKAT štabo viršininkas J. Gečas buvo įpareigotas peržiūrèti visas Apsaugos tarnybos sudarytas sutartis ${ }^{105}$.

Siekiant išvengti įvairių partiju, judèjimu, organizaciju destruktyvios veiklos ir Krašto apsaugos departamento padalinius sutelkti vien tik iškeltoms užduotims vykdyti, Krašto apsaugos departamento sistema buvo depolitizuota. $1991 \mathrm{~m}$. liepos $1 \mathrm{~d}$. buvo išleistas įsakymas „Dẻl Krašto apsaugos departamento ir jo struktūrų depolitizavimo". Pagal šį įsakymą Krašto apsaugos departamento ir jo padalinių darbuotojai, pradẻdami dirbti krašto apsaugos sistemoje arba stodami į Krašto apsaugos tarnybą, privalëjo sustabdyti savo igaliojimus bet kokioje visuomeninèje ar politinejje organizacijoje $\mathrm{e}^{106}$.

Tai buvo būtinas ir laiku išleistas įsakymas, nes partiju ir judejjimų kišimasis į krašto apsaugos sistemos padaliniu bei departamento veiklą èmė trukdyti normaliam darbui.

Greitai praktiškai buvo įsitikinta, kad norint deramai tvarkyti jaunuoliu įskaitą ir prireikus organizuoti naujoku šaukimą krašto apsaugos tarnybon, vien apskričių komendantūru neužtenka. 1991 m. gegužès 29 d. KAD generalinis direktorius įsakẻ šalia 8 apskričių komendantūru įsteigti 37 joms pavaldžias rajonų komendantūras ${ }^{107}$.

\footnotetext{
${ }^{104}$ Dèl generalinio direktoriaus pavaduotojų paskyrimo. KAD $1991 \mathrm{~m}$. birželio 12 d. įsakymas Nr. 73 // Ten pat. - P. 44-45.

${ }^{105}$ Dèl KAD Apsaugos tarnybos pavaldumo pakeitimo. KAD $1991 \mathrm{~m}$. balandžio 16 d. įsakymas Nr. 47 // Ten pat. - P. 30.

${ }^{106}$ Dèl Krašto apsaugos departamento ir jo struktūrų depolitizavimo. KAD $1991 \mathrm{~m}$. liepos $1 \mathrm{~d}$. ịsakymas Nr. 80 // Ten pat. - P. 48.

${ }^{107}$ Dèl komendantūrų organizavimo. KAD 1991 m. gegužès 29 d. įsakymas Nr. 61 // Ten pat. P. 38-39.
} 
Kruopščiai buvo renkamos rajonų komendantų kandidatūros. Kiekvieno būsimo komendanto kandidatūra buvo svarstoma departamento kolegijos posèdžiuose ${ }^{108}$.

KAD vadovybės sprendimą palaikè ir Lietuvos $\mathrm{Vy}-$ riausybè. $1991 \mathrm{~m}$. liepos $31 \mathrm{~d}$. Lietuvos Vyriausybė prièmé sprendimą šalia Alytaus, Kauno, Klaipédos, Marijampolès, Panevėžio, Šiaulių, Utenos ir Vilniaus apskričių komendantūrų kiekviename rajone ịkurti rajonų komendantūras. Pagal ši potvarkị Krašto apsaugos departamentas turëjo nustatyti rajonų komendantūru pavaldumą atitinkamų apskričių komendantūru komendantams ${ }^{109}$.

Apskričių komendantūros vykdè ir atitinkamų miestų bei rajonų komendantūrų funkcijas.

Komendantūrų apsaugai užtikrinti, Krašto apsaugos sistemos darbuotoju drausmei ir tvarkai palaikyti miestų ir rajonu teritorijose komendantūroms reikèjo daugiau žmonių. Šiam tikslui $1991 \mathrm{~m}$. rugpjūčio 26 d. buvo nutarta kiekvienoje apskrities komendantūroje ịkurti komendantinius būrius. Komendantinius būrius buvo leista formuoti mišriu principu: iš SKAT savanoriu, samdant reikalingos kvalifikacijos civilinius specialistus, pašaukiant šaukiamojo amžiaus jaunuolius ir įskaitant jų tarnybą kaip tikrają krašto apsaugos tarnybą ${ }^{110}$.

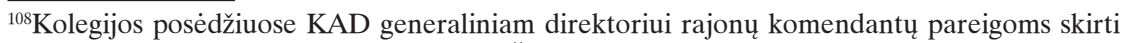
rekomenduoti šie darbuotojai: J. Purlys - Šilutès r., E. Musteikis - Kretingos r., J. Rutelionis - Lazdijų r., S. Bartuška - Varénos r., A. Grabažius - Ignalinos r., A. Balanda - Molètų r., A. Jasiulionis - Švenčionių r., A. Aglinskas - Zarasų r., L. Kleinauskas - Joniškio r., E. Kleivinis - Kelmès r., V. Linkevičius - Biržų r., R. Žipas - Rokiškio r., P. Sapkauskas - Anykščių r., A. Grinevičius - Ukmergès r., A. Gudašis - Širvintų r., P. Žilinskas - Trakų r., A. Gimžauskas - Kaišiadorių r., V. Smagurauskas - Kėdainių r., A. Valinčius - Prienų r., G. Dubickas - Šakių r. / KAD kolegijos posèdžių protokolai Nr. 3-6, 1991 m. birželio 18-21 d. // KAMEA (byla nenumeruota).

${ }^{109}$ Lietuvos Respublikos Vyriausybès $1991 \mathrm{~m}$. liepos 31 d. potvarkis Nr. 496p // Ten pat. ${ }^{110}$ Dèl komendantinių būrių įkūrimo. KAD 1991 m. rugpjūčio 26 d. įsakymas Nr. 171 // Krašto apsaugos departamento generalinio direktoriaus ir krašto apsaugos ministro įsakymų rinkinys. 1991 m. - P. 77.
} 


\section{Rugpjūčio pučo Maskvoje atgarsiai Lietuvoje}

Nepaprastai sudètinga ir ịtempta padètis susidarè rugpjūčio pučo Maskvoje dienomis. Kariškiams vieną po kito grobiant Lietuvai svarbius objektus, rugpjūčio 19 d. 11 val. 30 min. susirinko Laikinoji gynybos vadovybė aptarti susidariusios situacijos ir savo būsimų veiksmų. Reikèjo atsakyti i du labai svarbius klausimus: ar Lietuva priešinsis SSRS agresijai ir kaip reaguoti į SSRS kariškių reikalavimą nuginkluoti Krašto apsaugos departamentą.

Laikinoji gynybos vadovybè vienbalsiai nusprendè laikytis anksčiau priimtų nuostatų: ginti numatytus objektus, i jų sąrašą įtraukti ir Vidaus reikalų ministerijos pastatą ${ }^{111}$.

Vykdydamas Laikinosios gynybos vadovybės sprendimą, rugpjūčio 19 d. KAD generalinis direktorius įsakè Savanoriškajai krašto apsaugos tarnybai, KAD Mokomajam junginiui, Pasienio apsaugos tarnybai su ginklu ginti Lietuvos Respublikos Aukščiausiosios Tarybos ir Vyriausybès rūmus. Tuo pačiu įsakymu krašto apsaugos sistemos darbuotojai buvo ippareigoti blogiausiu atveju - SSRS ginkluotosioms pajègoms užėmus Aukščiausiosios Tarybos ir Vyriausybès rūmus - organizuoti ir vykdyti pilietinio pasipriešinimo akcijas visoje Lietuvos teritorijoje naudojant nesmurtinio pasipriešinimo metodiką ${ }^{112}$.

Per trumpą laiką KAD vyrai Aukščiausiosios Tarybos rūmus gana gerai parengè gynybai. Buvo įrengti nauji medicinos punktai, atgabenta daugiau neštuvu, vaistu, padidintos smèlio maišu tvirtovès, užminuota laukymè ties Nerimi.

Žinoma, grioviai, barikados, užminuotas laukas prie Neries aplink Aukščiausiosios Tarybos rūmus tebuvo dau-

\footnotetext{
${ }^{111}$ Laikinosios gynybos vadovybès 1991 m. rugpjūčio 19 d. posėdžio protokolas. Rankraštis // Lietuvos Respublikos Seimo archyvas (byla nenumeruota).

${ }^{112}$ Dèl KAD padalinių veiksmų ypatingos situacijos metu. KAD $1991 \mathrm{~m}$. rugpjūčio 19 d. isakymas Nr. 160 // Krašto apsaugos departamento generalinio direktoriaus ir krašto apsaugos ministro įsakymų rinkinys. $1991 \mathrm{~m}$. - P. 73-74.
} 
giau simbolinis dalykas, negalejęs padèti atremti didesnio karinio puolimo, - praejus pavojui prisiminė SKAT štabo viršininkas J. Gečas, - bet buvo būtina parodyti, kad priešinamasi, ir tai užfiksuoti ${ }^{113}$.

Rugpjūčio 19 d. Aukščiausiosios Tarybos Pirmininkas V. Landsbergis kalbejosi su Pabaltijo karinès apygardos vadu gen. F. Kuzminu. F. Kuzminas primygtinai reikalavo, kad V. Landsbergis įsakytų nuginkluoti KAD padalinius. İ tai jam buvo atsakyta, kad KAD - neginkluota organizacija, o ginkluoti sargybiniai prižiūri tik svarbiausius valstybès objektus ${ }^{114}$.

Maskvoje prasidejjus rugpjūčio pučui, KAD generalinis direktorius, siekdamas užtikrinti krašto apsaugos sistemos valdymo operatyvumą SSRS agresijos prieš Lietuvą sąlygomis, apskričiu ir rajonu komendantams pavedé garantuoti operatyvų karini valdymą šalies miestuose ir rajonuose. Savanoriškosios krašto apsaugos tarnybos, Mokomojo junginio vadai turëjo griežtai vykdyti atitinkamo komendanto įsakymus.

Rugpjūčio 21 d. 22 val. 45 min., kai Aukščiausiosios Tarybos rūmus, norèdami juos apsaugoti, supo tūkstančiai žmoniu, Sapiegos gatvèje dislokuotos specialiosios paskirties kuopos kariai mašina prasiveržè pro pirmaji rūmų apsaugos postą, esantį netoli nuo Pedagoginio instituto tilto. Prasiveržę prie rūmu, jie apsisuko ir tuo pačiu keliu norejjo grįžti atgal. Poste budeję SKAT vyrai sustabde automobilị. Kariams atsisakius išlipti, $d u$ buvo išlaipinti jèga, o po to iš mašinos pasipylè automatu šūviai, buvo išmesti du sprogstamieji paketai. Aukščiausiosios Tarybos gynejjai atsakè ugnimi. Susišaudymo metu žuvo 28 metų savanoris statybininkas iš Alytaus Artūras Sakalauskas ${ }^{115}$.

\footnotetext{
${ }^{113}$ Girdvainis J. Ant parako statinès // Respublika. - 1991, rugsèjo 20.

${ }^{114}$ Gaivenis V. Evakuacija be kvorumo // Ten pat

${ }^{115}$ Telksnys F. Paskutinès pučo aukos // Ten pat. - 1991, rugpjūčio 23.
} 
Tomis dienomis sovietiniai kariai siautèjo visoje Lietuvoje. Rugpjūčio $20 \mathrm{~d}$. buvo gauta informacijos, kad agresyviems veiksmams rengiasi Alytaus desantininku pulkas, jūru péstininkai. Klaipédoje buvo užpulti 4 muitiniu postai. Kaune sovietiniai kariai užèmè Lietuvos šaulių sąjungos būstinę. Daugelyje Lietuvos vietoviu represinès jègos elgèsi agresyviai, plèšikavo. Panevėžio merei buvo pareikšta, kad mieste negali būti leidžiami nepriklausomi laikraščiai, turi būti uždraustos kitos nepriklausomos žiniasklaidos priemonès ir t. t. ${ }^{116}$

Rugpjūčio 23 d. SKAT štabo viršininkas J. Gečas buvo ipareigotas organizuoti visų buvusių KPSS komitetu, archyvų stebejjimą, kartu su visuomene, policija siekti sutrukdyti išvežti archyvus, jei sutrukdyti neįmanoma - registruoti išvežančių archyvus ir kitą turtą mašinų numerius, markes.

Pasienio apsaugos tarnybos viršininkas V. Česnulevičius buvo ịpareigotas kartu su policijos pareigūnais sustiprinti vykstančio per valstybės sieną autotransporto kontrolę, nepraleisti nè vienos mašinos, išvežančios iš Lietuvos archyvinius dokumentus ar kitas vertybes ${ }^{117}$.

Tačiau pučas žlugo...

1991 m. rugsëjo 6 d. SSRS Valstybės taryba prièmė nutarimą, kuriuo pripažino Lietuvos nepriklausomybę ${ }^{118}$.

Žlugus pučui Maskvoje, Lietuvos Respublikos Aukščiausiosios Tarybos Prezidiumas laisvės ir nepriklausomybės gynëjų didvyriškumą įvertino ir apdovanojo šiuos Krašto apsaugos departamento darbuotojus:

1-ojo laipsnio Vyčio kryžiaus ordinu - Artūrą Sakalauską, Savanoriškosios krašto apsaugos tarnybos Alytaus rinktinès savanorị (po mirties); Gintarą Žaginį, Pasienio ap-

\footnotetext{
${ }^{116}$ Lietuva // Lietuvos aidas. - 1991, rugpjūčio 21.

${ }^{117}$ Dèl kontrolès sustiprinimo apsaugant Lietuvos Respublikos turtą. KAD 1991 m. rugpjūčio 23 d. įsakymas Nr. 169 // Krašto apsaugos departamento generalinio direktoriaus ir krašto apsaugos ministro įsakymų rinkinys. $1991 \mathrm{~m}$. - P. 76.

${ }^{118}$ SSRS Valstybès tarybos nutarimas dẻl Lietuvos Respublikos nepriklausomybès pripažinimo // Lietuvos aidas. - 1991, rugsėjo 10.
} 
saugos tarnybos Šalčininkų užkardos pamainos viršininką (po mirties);

4-ojo laipsnio Vyčio kryžiaus ordinu - Gintarą Danieliu, Pasienio apsaugos tarnybos viršininko pavaduotoją; Gintarą Dapku, Pasienio apsaugos tarnybos Śalčininkų užkardos vado pavaduotoją; Donatą Kaulini, Pasienio apsaugos tarnybos Biržų užkardos šaulį; Rimą Litviną, Mokomojo junginio štabo skyriaus viršininką; Romualdą Gintautą, Pasienio apsaugos tarnybos Šalčininkų užkardos pamainos viršininką; Vidmantą Vaitku, Pasienio apsaugos tarnybos Šalčininkų užkardos pamainos viršininką;

5-ojo laipsnio Vyčio kryžiaus ordinu - Vidą Čepuli, Savanoriškosios krašto apsaugos tarnybos Ryšių skyriaus viršininką; Eugeniju Šepeti, Pasienio apsaugos tarnybos Rokiškio užkardos vadą ${ }^{119}$.

Už pasiaukojamą darbą ir parodytą sumanumą užkertant kelią galimiems mėginimams įvykdyti valstybini perversmą Lietuvos Vyriausybė pareiškẻ padèką ir skyrè pinigines trijų mėnesinių tarnybinių atlyginimų dydžio premijas Krašto apsaugos departamento generaliniam direktoriui A. Butkevičiui ir jo pavaduotojams J. Paužoliui ir N. Vidrinskui ${ }^{120}$.

Krašto apsaugos departamento generalinis direktorius savo ruožtu už nepriekaištingą darbą, pasiaukojimą ir ryžtą pučo metu premijavo 1085 Krašto apsaugos departamento darbuotojus ${ }^{121}$.

\footnotetext{
${ }^{119}$ Dèl apdovanojimo Vyčio Kryžiaus ordinu. 1991 m. rugsejjo 6 d. Lietuvos Respublikos Aukščiausiosios Tarybos nutarimas // Lietuvos Respublikos Aukščiausiosios Tarybos ir Vyriausybès žinios. - 1991. - Nr. 27. - P. 1273.

${ }^{120} 1991$ m. rugsejjo 30 d. Lietuvos Respublikos Vyriausybès potvarkis Nr. 693p // KAMEA (byla nenumeruota).

${ }^{121}$ Dèl premijų KAD sistemos darbuotojams mokejimo. KAD 1991 m. spalio 30 d. įsakymas Nr. 243 // Krašto apsaugos departamento generalinio direktoriaus ir krašto apsaugos ministro i̊sakymų rinkinys. 1991 m. - P. 101-109.
} 


\section{KAD veiklos pokyčiai po rugpjūčio pučo}

Žlugus 1991 m. rugpjūčio pučui Maskvoje, Lietuvos Aukščiausiosios Tarybos nutarimu nuo rugpjūčio 26 d. turèjo būti užtikrinta visų Lietuvos Respublikos valstybės sienu apsauga ir įvestas pasienio ruožo režimas, taip pat atnaujintas Lietuvos Respublikos vizu išdavimas ${ }^{122}$.

Ši darbą Lietuvos Respublikos Vyriausybè pavedė dirbti Krašto apsaugos departamentui. Nutarime buvo pažymèta, kad „Krašto apsaugos departamentas nuo $1991 \mathrm{~m}$. rugpjūčio $26 \mathrm{~d}$. turi užtikrinti Lietuvos Respublikos-Lenkijos Respublikos valstybés sienos, taip pat kitų iki šiol TSRS valstybès saugumo komiteto pasienio kariuomenès saugotu sienų apsaugą, laikinai (kol Krašto apsaugos departamentas visiškai perims jų apsaugą bei užtikrins pasienio ruožo režimą) ją vykdydama kartu su TSRS valstybès saugumo komiteto pasienio kariuomene".

Tame pačiame nutarime buvo įsakyta nuo rugpjūčio 25 d. apginkluoti Pasienio apsaugos tarnybos pareigūnus šaunamaisiais ginklais laikantis Lietuvos Respublikos įstatymu, Lietuvos Respublikos Vyriausybės normatyviniu aktų nustatytos ginkluotès įsigijimo, apskaitos, laikymo ir naudojimo tvarkos ${ }^{123}$.

Nuo rugpjūčio $26 \mathrm{~d}$. buvo sustabdyta SSRS Lietuvos respublikinès muitinès veikla. Jos funkcijas perėmė Lietuvos Respublikos muitinès departamentas ${ }^{124}$.

Lietuvos Vyriausybe taip pat buvo nutarusi, kad nuo rugpjūčio 26 d. ginkluoti KAD Pasienio apsaugos tarnybos pareigūnai valstybès sieną laikinai saugos kartu su ją iki šiol

\footnotetext{
${ }^{122}$ Dèl Lietuvos Respublikos valstybės sienų. Lietuvos Respublikos Aukščiausiosios Tarybos nutarimas // Lietuvos Respublikos Aukščiausiosios Tarybos ir Vyriausybės žinios. - 1991. - Nr. 25. - P. 1151.

${ }^{123}$ Dèl Lietuvos Respublikos valstybinių sienų apsaugos ir Krašto apsaugos departamento Pasienio apsaugos tarnybos pareigūnų apginklavimo. 1991 m. rugpjūčio 25 d. Lietuvos Respublikos Vyriausybės nutarimas // Ten pat. - Nr. 28. - P. 1352.

${ }^{124}$ Dèl TSRS Lietuvos respublikinès muitinès veiklos nutraukimo. $1991 \mathrm{~m}$. rugpjūčio 25 d. Lietuvos Respublikos Vyriausybès nutarimas // Ten pat. - Nr. 26. - P. 1238.
} 
kontroliavusia sovietine pasienio kariuomene. Tačiau tam reikejjo pasiruošti. Tai buvo padaryta truputi vèliau, nei buvo ipareigojusi Vyriausybe் ${ }^{125}$.

Rugsėjo 3 d. Vyriausybė pavedė Krašto apsaugos departamentui Pasienio apsaugos tarnyboje įsteigti pasų kontrolès padalinị. Šio padalinio pareigūnams laikinai buvo pavesta vykdyti konsulines funkcijas.

Darbas buvo naujas, todèl greitai surinkti jam darbuotojus buvo ne taip jau paprasta. Siam skyriui įkurti Pasienio apsaugos tarnybos vadovai gavo savaitę laiko. Dar prieš pradedant veikti šiam skyriui, darbas buvo pavestas specialiai parinktiems ir apmokytiems PAT darbuotojams. Šiuos darbuotojus instruktavo Užsienio reikalų ministerijos atsakingi pareigūnai.

Vizu išdavimas, registravimas ir apskaita buvo atliekama Lazdiju, Nidos, Pagėgiu, Kybartu, Kalvarijos, Druskininku, Šalčininku, Saločių, Buknaičiu, Medininku, Būtingės pasienio apsaugos postuose, Vilniaus aerouoste bei Klaipèdos uoste. Atsakingu už vizu išdavimą ir kontrolę Pasienio apsaugos tarnyboje buvo paskirtas Pasienio apsaugos tarnybos skyriaus viršininko pavaduotojas E. Leščinskas ${ }^{126}$.

Ypač sunkus baras Lietuvos pasieniečiams buvo Lazdiju muitinè. Prie muitinès nusidriekdavo kilometrinès eilès. Čia dirbantiems Pasienio apsaugos tarnybos pareigūnams reikèjo ypatingos ištvermès ir kantrybès. Ne vienas šiame poste ir suklupo, nes $1991 \mathrm{~m}$. spalio mèn. pasieniečio atlyginimas buvo apie 500, užkardos viršininko - 800 rubliu, o už praleidimą prie muitinès be eilès siūlomo kyšio dydis siekè net 40 tūkst. rublių ${ }^{127}$.

\footnotetext{
${ }^{125}$ Jarmalavičius R. Skyrybos // Respublika. - 1991, rugpjūčio 27.

${ }^{126}$ KAD 1991 m. rugsejo 6 d. KAD įsakymas Nr. 185 // Krašto apsaugos departamento generalinio direktoriaus ir krašto apsaugos ministro įsakymų rinkinys. $1991 \mathrm{~m}$. - P. 81; Dèl telefonu irengimo. 1991 m. rugsejo 9 d. KAD raštas Ryšių ministerijai // KAMEA. - F. 1. - Ap. 1. - B. 25. - L. 108.

${ }^{127}$ Jarmalavičius R. Purvini Lietuvos vartai // Respublika. - 1991, spalio 2.
} 
Panašiu problemų buvo ir kitur, su jomis buvo kovojama. Maždaug per metus nuo Pasienio tarnybos įkūrimo dienos buvo atleista per 350 darbuotoju, 200 skirtos administracinès nuobaudos, 15 buvusių pasieniečių už nusikaltimus buvo perduota prokuratūrai ${ }^{128}$.

Nors Lietuva buvo pripažinta nepriklausoma šalimi, čia dar liko milžiniška sovietinè kariuomenè. Sovietinės karinès dalys Lietuvoje užèmė 68000 ha, arba 1,2 proc., Lietuvos teritorijos. Jos buvo dislokuotos visuose didžiuosiuose šalies miestuose ir sostinëje Vilniuje ${ }^{129}$. Visa ši kariuomené bet kada galejo imtis agresyviu veiksmų. Ją ir toliau buvo būtina stebèti ir apie jos veiklą kaupti informaciją.

Atkūrus Lietuvos nepriklausomybę, Lietuvoje funkcionavusi civilinès gynybos sistema buvo sudedamoji SSRS civilinès gynybos sistemos dalis. Ši sistema buvo pritaikyta didžiulei valstybei, turinčiai milžinišką teritoriją, kur visuomet galima evakuoti nelaimės ar katastrofos ištiktus žmones. Tačiau praktika parodè, jog, ištikus didesnèms stichinèms nelaimèms, tokioms katastrofoms kaip Černobylio, o ir mažesnèms, ši sistema funkcionuoja blogai. Tokia civilinės gynybos sistema Lietuvai netiko. Reikejjo viską apsvarstyti iš naujo, tačiau iš pradžiu to padaryti buvo neįmanoma, nes pirmiausia šią problemą reikèjo spręsti politikams. Tai buvo padaryta tik $1991 \mathrm{~m}$. rugsejo mènesi.

Remiantis Lietuvos Respublikos Vyriausybès ir SSRS Vyriausybès susitarimu, taip pat Lietuvos Respublikos Vyriausybès $1991 \mathrm{~m}$. rugsëjo $18 \mathrm{~d}$. nutarimu Nr. 387 („Dẻl pavedimo vykdyti civilinès apsaugos funkcijas Krašto apsaugos departamentui“), buvusi sajunginio-respublikinio pavaldumo valstybės institucija - civilinès gynybos sistema perejjo Lietuvos Respublikos Vyriausybės žinion. Nuo 1991 m. rugsejjo 18 d. ji buvo įtraukta į krašto apsaugos sistemą Krašto apsaugos departamento tarnybos teisemis.

\footnotetext{
${ }^{128}$ Sienos jau mūsų // Karys. - 1991. - Nr. 11. - P. 8.

${ }^{129}$ Butkevičius A. Nacionalinis saugumas ir Baltijos regionas // Ten pat. - 1992. - Nr. 2. - P. 5-6.
} 
Pertvarkant esamą civilinės gynybos sistemą buvo siekiama ją pritaikyti Lietuvos valstybès poreikiams, apsaugoti šalies gyventojus avariju, katastrofu, gaivaliniu nelaimiu, diversiju ar kariniu konfliktu atvejais. O Lietuvoje tuo metu buvo net 68 chemini pavojų keliančios įmonès.

Lietuvos Respublikos civilinės gynybos štabo ir Krašto apsaugos departamento veiklai koordinuoti buvo paskirtas Gediminas Pulokas. Jis buvo tiesiogiai pavaldus Krašto apsaugos departamento generaliniam direktoriui.

Žlugus pučui KAD vadovybė susidūrè dar su viena problema. Departamentą užplūdo norintys tarnauti departamente buvę ar dar tarnaujantys sovietinès kariuomenès karininkai. 1991 m. rugsẻjo viduryje norą pereiti dirbti ic KAD sistemą buvo pareiškę 94 karininkai: 10 pulkininku, 23 papulkininkiai, 21 majoras, 24 kapitonai, 16 leitenantų. Iš jų 58 dar tebetarnavo sovietinejje kariuomenèje, kiti jau buvo išeję i ̨ atsargą.

Šis klausimas $1991 \mathrm{~m}$. rugsëjo $24 \mathrm{~d}$. buvo apsvarstytas departamento kolegijos posèdyje. Jame buvo konstatuota, kad daugelis pareiškusių nora tarnauti krašto apsaugos sistemoje karininku yra igiję tokias karines specialybes, kurios nebus reikalingos planuojamuose Lietuvos kariniuose padaliniuose. Kolegija nusprendè sudaryti mandatinę komisiją, kuri įvertintų karininku, tarnaujančiu arba jau baigusių tarnybą sovietineje kariuomenėje, tinkamumą krašto apsaugos tarnybai. Buvo nustatyta, kad karininku, norinčiu tarnauti krašto apsaugos sistemoje, registravimas turi būti baigtas 1991 m. gruodžio $31 \mathrm{~d}$.

Kolegijos nutarimu miestų ir rajonų komendantai turejjo surinkti ir pateikti apie karininkus, pretenduojančius dirbti krašto apsaugos sistemoje, išsamias žinias ${ }^{130}$.

Krašto apsaugos sistemai plečiantis, daugëjant jai užduočiu, KAD štabas pasidarè nepajègus operatyviai vadovauti departamentui, nes nebuvo nustatyta aiški ir tiksli visu

${ }^{130}$ Krašto apsaugos departamento prie Lietuvos Respublikos Vyriausybės Kolegijos posėdžio 1991 m. rugsèjo 24 d. protokolas Nr. 15 // KAMEA (byla nenumeruota). 
departamento padaliniu pavaldumo schema. Štabe trūko kai kurių tarnybu, kurios galètų užtikrinti, kad laiku būtu pateikiami siūlymai vadovybei, igyvendinami priimti sprendimai, kontroliuojama, kaip jie vykdomi.

Siekdamas išspręsti susidariusią problemą, $1991 \mathrm{~m}$. rugpjūčio $20 \mathrm{~d}$. generalinis direktorius nurodè, kad visos Krašto apsaugos departamento karinès formuotès ir tarnybos yra pavaldžios jam, o joms vadovauja štabas. Šiuo įsakymu karinių formuočių bei tarnybų vadai ir viršininkai buvo įpareigoti susirašinèti tik per štabą. Štabo viršininko nurodymus ir reikalavimus privalëjo vykdyti visų karinių formuočiu vadovai.

Tuo pačiu įsakymu štabo viršininkas iki rugsëjo $1 \mathrm{~d}$. buvo ịpareigotas generaliniam direktoriui pateikti naują štabo organizacinès struktūros projektą, o štabo skyrių viršininkai iki rugpjūčio $20 \mathrm{~d}$. štabo viršininko pavaduotojui - siūlymus dèl skyriu reorganizavimo, darbo apimties apribojimo, pareiginiu funkciju kiekvienam darbuotojui nustatymo, nurodant jo kategorija, darbo apimti, pareigas ir atsakomybę. Štabo viršininko pavaduotojas iki rugpjūčio $25 \mathrm{~d}$. turèjo sudaryti štabo struktūros projektą, užtikrinantị tvirtą ir nuolatinį vadovavimą visose susidariusiose situacijose ${ }^{131}$.

Tačiau tuo metu nepavyko pasiekti, kad štabo veikla užtikrintų krašto apsaugos sistemos padalinių ir KAD vadovybès poreikius.

Krašto apsaugos departamento darbuotoju - kariu veiklai bei tarpusavio santykiams reglamentuoti reikejjo statutų. Tačiau tai irgi buvo gana sudètinga problema. Statutus iš esmès reikejjo kurti naujus. Buvo Lietuvos Respublikos iki 1940 m. galioję statutai, tačiau prabėgę 50 metu gyvenimą gerokai pakeitè. Nors tuomečiai kariuomenès statutai buvo gana tobuli, šiems laikams jie netiko. Reikejo, pasirèmus modernių kariuomeniu statutais, kurti naujus.

\footnotetext{
${ }^{131}$ Dèl Krašto apsaugos departamento štabo darbo veiklos tobulinimo ir jo struktūros reorganizavimo. KAD 1991 m. rugpjūčio 20 d. įsakymas Nr. 162 // Krašto apsaugos departamento generalinio direktoriaus ir krašto apsaugos ministro ịsakymų rinkinys. 1991 m. - P. 74.
} 
Dar 1990 m. pabaigoje buvo parengtas pirmojo Lietuvos kariuomenès statuto - Rikiuotès statuto - projektas. Jame buvo išsamiai aptarti karių veiksmai iki bataliono lygmens imtinai. Gruodžio $5 \mathrm{~d}$. šį statuto projektą patvirtino KAD generalinis direktorius. Jis turëjo būti taikomas tarnyboje. Pastabos, pasiūlymai dèl šio statuto tobulinimo turëjo būti siunčiami į departamentą ${ }^{132}$.

Keleto kitu statutu projektai buvo parengti $1991 \mathrm{~m}$. vasarą. Norèdamas juos išbandyti, $1991 \mathrm{~m}$. rugsèjo $4 \mathrm{~d}$. KAD generalinis direktorius įsakė nuo $1991 \mathrm{~m}$. rugsèjo $10 \mathrm{~d}$. laikinai vadovautis Vidaus tarnybos, Drausmès, Sargybu ir Rikiuotès statutu projektais. Generalinio direktoriaus pavaduotojams, valdybu, tarnybu, skyrių viršininkams, komendantams, padalinių vadams buvo pavesta iki $1991 \mathrm{~m}$. gruodžio 1 d. KAD Mokymo valdybai pateikti pasiūlymus ir atsiliepimus apie šiu statutu projektus ${ }^{133}$.

Tai buvo pagrindiniai statutai, tačiau dar turèjo būti parengti ir kiti, reglamentuojantys ịvairių tarnybų darbą. Siekdamas suaktyvinti ir koordinuoti statutu ir mokomosios literatūros rengimo procesą, $1991 \mathrm{~m}$. rugsëjo $10 \mathrm{~d}$. KAD generalinis direktorius įsakė valdybu, tarnybu, skyriu, Karininku kursu viršininkams, komendantams skirti daugiau dėmesio statutų, nuostatu, reglamentuojančiu pavaldžių formuočiu veiklą, ir mokomosios literatūros rengimui. Buvo įsakyta statutams ir mokomajai literatūrai karine tematika rengti sudaryti darbo grupes ir tinkamas darbui sąlygas. Šis darbas turèjo būti derinamas su Mokymo valdyba. Mokymo valdybos viršininkas iki $1991 \mathrm{~m}$. spalio $20 \mathrm{~d}$. turëjo apibendrinti atliekamo darbo rezultatus ir parengti statutu bei mokomosios literatūros leidimo planą ${ }^{134}$.

\footnotetext{
${ }^{132}$ Dèl rikiuotès statuto projekto. KAD 1990 m. gruodžio 5 d. įsakymas // Krašto apsaugos departamento generalinio direktoriaus ịsakymų rinkinys. 1990 m. - P. 14.

${ }^{133}$ Dèl Vidaus tarnybos, Drausmès, Sargybų ir Rikiuotès statutų projektų. KAD $1991 \mathrm{~m}$. rugsejjo 4 d. įsakymas Nr. 177 // Krašto apsaugos departamento generalinio direktoriaus ir krašto apsaugos ministro įsakymų rinkinys. $1991 \mathrm{~m}$. - P. 79.

${ }^{134}$ Dèl statutų (nuostatų) ir mokomosios literatūros rengimo. KAD $1991 \mathrm{~m}$. rugsèjo $10 \mathrm{~d}$. i̊sakymas Nr. 187 // Ten pat. - P. 81-82.
} 
Plètojant krašto apsaugos sistemą iškilo krašto apsaugos formuočiu apginklavimo klausimas. Juo labiau kad iki tol KAD buvo menkai ginkluota organizacija, nes pirmieji ginklai oficialiai buvo gauti tik $1990 \mathrm{~m}$. Apsaugos tarnybai apginkluoti. Vèliau, sausio įvykiu metu, buvo gauta ginklų partija iš Lietuvos banko bei medžiotoju parduotuviu, po rugpjūčio pučo Maskvoje nuginklavus KGB padalinius Lietuvoje. Taip pat šiek tiek ginklų buvo nupirkta, tačiau ginklu problema besikuriančiai Lietuvos kariuomenei buvo viena aktualiausių. Šiai problemai spręsti $1991 \mathrm{~m}$. rugsèjo $19 \mathrm{~d}$. buvo sudaryta Vyriausiojo štabo viršininko N. Vidrinsko vadovaujama komisija. İ komisiją buvo paskirti Mokymo valdybos viršininkas Z. Kulys, PAT viršininkas V. Česnulevičius, Mokomojo junginio vadas Č. Jezerskas, Informacijos valdybos viršininkas Š. Vasiliauskas, SKAT štabo viršininkas J. Gečas, Imuniteto skyriaus viršininkas L. Bumbulis, Ryšių skyriaus viršininkas V. Žagaras, Inžinerinio-techninio skyriaus viršininkas A. Griška, Jūreivystės skyriaus viršininkas E. Miliauskas, Oro erdvės skyriaus specialistas Z. Vegelevičius, Operatyvinio skyriaus vyr. specialistas J. Noreika.

Komisija buvo ịpareigota išanalizuoti ir nuspręsti, i kokių šaliu ginkluotę ir techniką tikslinga orientuotis, nustatyti ginkluotés ir technikos rūšis bei tipus ir jų reikalingą kieki, suformuotu padaliniu ginkluotés ir technikos poreiki, parengti ginklavimo programa, nustatant jos vykdymo etapus ir turinị ${ }^{135}$. Tačiau ši komisija savo pasiūlymus pateikè jau Krašto apsaugos ministerijai.

Igyvendindama Lietuvos Respublikos laikinaji krašto apsaugos prievolès įstatymą, Lietuvos Respublikos $\mathrm{Vy}$ riausybė $1991 \mathrm{~m}$. spalio $10 \mathrm{~d}$. nutare paskelbti naujoku, gimusiu 1972 m., taip pat kitų vyresnio amžiaus Lietuvos Respublikos piliečiu, kurie privalo atlikti tikrają krašto apsau-

\footnotetext{
${ }^{135}$ Dèl komisijos ginkluotès klausimams spręsti paskyrimo. KAD $1991 \mathrm{~m}$. rugsejjo 19 d. įsakymas // Ten pat. - P. 86 .
} 
gos tarnybą, šaukimą tikrojon krašto apsaugos tarnybon. Buvo nutarta pašaukti iki 7000 naujoku ${ }^{136}$.

Naujokų šaukimą organizuoti buvo pavesta jau Krašto apsaugos ministerijai ${ }^{137}$.

\section{Tarptautinių ryšių užmezgimas ir plètojimas}

Krašto apsaugos departamentui vykdant iškeltus uždavinius, juos teko glaudžiai sieti su politiniais sprendimais, nes $X X$ a. pabaigoje jau nè viena pasaulio valstybė negalejo vien savo jėgomis, vien savo ištekliais bei atsargomis užtikrinti nacionalinio saugumo. Tai galejo garantuoti tik kolektyvinio saugumo sistema.

Lietuvai, pradejjusiai kurti savo gynybines struktūras, tai buvo labai palankus momentas, nes tuo metu kaip tik pradejo formuotis bendra Europos saugumo sistema. Sis procesas buvo glaudžiai susijęs su Varšuvos bloko irimo procesais, ir Lietuvai reikëjo kuo greičiau pralaužti SSRS vykdomą blokadą, sukurti struktūras, užtikrinančias Lietuvos, kaip kolektyvinio saugumo sistemos narès, funkcijas. Visą ši darbą reikëjo suplanuoti, gerai įvertinti savo tiek ekonomines, tiek materialines galimybes, įmonių išteklius. Šio darbo, be visu kitu, ir ėmėsi Krašto apsaugos departamentas ${ }^{138}$.

Kol Lietuva buvo izoliuota, Krašto apsaugos departamento vadovybė dejjo daug pastangu, kad būtų užmegzti tarptautiniai ryšiai su įvairių šaliu karinemis struktūromis.

1990 m. gruodžio 10-14 d. Švedijos civilinès saugos organizacijos kvietimu šioje šalyje viešejo A. Butkevičius, V. Vaitkaitis, I. Stankovičius, R. Daunoravičiūtè ${ }^{139}$.

\footnotetext{
${ }^{136}$ Dèl naujokų šaukimo tikrojon krašto apsaugos ir alternatyviojon (darbo) tarnybon. Lietuvos Respublikos Vyriausybès 1991 m. spalio 10 d. nutarimas Nr. 413 // Lietuvos Respublikos Aukščiausiosios Tarybos ir Vyriausybės žinios. - 1991. - Nr. 31. - P. 1498-1499.

${ }^{137}$ Ten pat.

${ }^{138}$ Lietuvoje bus reguliari kariuomenè ar nacionalinè gvardija // Karys. - 1991. - Nr.1. - P. 3. ${ }^{139}$ A. Butkevičius 1990 m. gruodžio 7 d. raštas LR Vyriausybei // KAMEA (byla nenumeruota).
} 
1991 m. balandžio 17-23 d. A. Butkevičius viešèjo Švedijoje ir Didžiojoje Britanijoje. Švedijos sostinejje Stokholme A. Butkevičius dalyvavo Švedijos civilinės gynybos vadovybės surengtoje konferencijoje „Baltijos valstybès, TSRS ir Švedija“" kurioje buvo svarstomi Baltijos valstybiu saugumo, ekonominio bendradarbiavimo klausimai.

Didžiojoje Britanijoje A. Butkevičius susitiko su Tarptautinio strategijos tyrimu instituto direktoriumi Maiklu Du, Užsienio reikalų ministerijos ypatinguoju patarëju politikos klausimais Edvardu Biokhamu, Civilinès gynybos divizijos vadais ${ }^{140}$.

Gegužès 9-10 d. A. Butkevičius Lenkijoje susitiko su Lenkijos Respublikos senatoriais A. Barovskiu (Barovski), S. Dembinskiu (Dembinski), Vyriausybės atstovais - gynybos ministro pavaduotoju V. Onuškevičiumi, vidaus reikalų ministro pavaduotoju (pabėgėlių ir internuotų užsienio piliečių klausimams spręsti) plk. Z. Skočylu (Skoczyl), patarëjais dr. A. Hainiču (Hainicz), T. Chabiera, E. Lasota, Lenkijos Respublikos Helsinkio komiteto atstovu M. Novickiu (Novicki). Siuos susitikimus organizavo Lenkijos Senato Tarptautinių tyrimų centro direktorius, ministras J. Novakovskis. Susitikimuose buvo aptarti Lenkijos saugumo politikos bruožai, jos santykiai su SSRS, Vokietija, Vengrija, ZSFR, Rumunija, Lenkijos dalyvavimo saugumo procese perspektyvos, santykiai su Lietuva, civilinès gynybos, gelbëjimo tarnybu bendradarbiavimas ${ }^{141}$.

Gegužès 16 d. jau Vilniuje įvyko susitikimas su Tarptautinès policijos šefu organizacijos vadovu plk. J. Nortonu (Norton), JAV konservatorių klubo prezidentu H. Filipsu (Philips) bei kitais svečiais iš Belgijos ir Vokietijos. KAD generaliniam direktoriui buvo įteiktas Tarptautinès policijos šefu organizacijos medalis.

Gegužès 19 d. susitikime su Gelopo (Gallyp) instituto atstovu G. Hildu buvo aptartos tolesnio bendradarbiavimo perspektyvos $^{142}$.

${ }^{140}$ Baltijos valstybiu interesai // Karys. - 1991. - Nr. 6. - P. 8.

${ }^{141}$ Krašto apsaugos departamento kronika // Ten pat. - Nr. 7. - P. 7.

${ }^{142}$ Ten pat. 
Birželio 12 d. Krašto apsaugos departamente lankėsi Kanados ambasados Maskvoje konsulas ir patarejjas R. Todas (Todd) ir Austrijos pasiuntinybès Maskvoje pirmoji sekretorè $\mathrm{F}$. Bedjè (Bedie).

Birželio 19-21 d. Maskvoje įvyko sąjunginio Taikos gynimo komiteto organizuota konferencija „Baltijos valstybių: Lietuvos, Latvijos ir Estijos - saugumo, taikos ir stabilumo problemos". Konferencijos tikslas - padèti valstybinèms SSRS ir Baltijos valstybiu delegacijoms suartėti derybose, pagelbèti atitinkamų delegacijų ekspertams geriau išanalizuoti iškilusias problemas neoficialioje aplinkoje.

Konferencijoje dalyvavo SSRS gynybos ministerijos ir generalinio štabo, SSRS vidaus reikalų ministerijos, SSRS užsienio reikalų ministerijos, SSRS, JAV ir Kanados probleminiu moksliniu tyrimu institutu, SSRS valstybès ir teisès instituto atstovai, Tarptautinės teisés, kariniu-politinių ir karinių-istoriniu tyrimų asociacijos, Nacionalinio saugumo problemų tyrimo centro specialistai, Rusijos Aukščiausiosios Tarybos atstovai, Latvijos vidaus reikalu ministras A. Vaznis, Latvijos Aukščiausiosios Tarybos deputatai, Latvijos visuomenès apsaugos departamento direktorius J. Baškers, Estijos mokslų akademijos akademikas E. Lipma (Lippmaa), Estijos Aukščiausiosios Tarybos deputatai, ekspertai, valstybės ministras Vaze Raivo, Lietuvos Krašto apsaugos departamento generalinis direktorius A. Butkevičius, Valstybinės delegacijos deryboms su SSRS ekspertu grupės koordinatorius J. Gečas ir KAD generalinio direktoriaus pavaduotojas I. Stankovičius.

Buvo aptarti juridiniai ir politiniai SSRS ir Lietuvos, Latvijos bei Estijos saugumo politikos aspektai, nacionalinio saugumo samprata, SSRS ir Baltijos valstybiu santykiuose atsiradusios konfrontacijos priežastys, šiu valstybių vidaus situaciją destabilizuojantys veiksniai, svarbiausios, skubiai spręstinos problemos, SSRS ir Lietuvos, Latvijos bei Estijos santykiu sureguliavimo galimybès, konfrontacijos šalinimo būdai, pasitikẻjimą stiprinančios priemonès. 
Birželio 20 d. A. Butkevičius Maskvoje susitiko su Austrijos pasiuntinybės gynybos atašè $M$. Troifaieriu (Troifaier) ${ }^{143}$.

Birželio 24-28 d. Śvedijos civilinès gynybos departamento kvietimu KAD generalinis direktorius A. Butkevičius dalyvavo Norvegijos, Danijos, Suomijos ir Švedijos civilinės gynybos departamentu organizuotoje konferencijoje Norvegijoje.

Savo kalboje, apžvelgęs chemijos gamyklu, Ignalinos atominès elektrinès bei esamos Lietuvos civilinès gynybos sistemos padèti, jis pažymèjo, kad efektyviu civilinès gynybos sistemos darbu yra suinteresuoti ne tik Lietuvos, bet ir kaimyninių valstybiu žmonès bei civilinės gynybos specialistai.

A. Butkevičius pabrèžè: „Manau, jog tai yra pakankamas pagrindas pradèti bendradarbiauti jau dabar, net ir su nepripažinta valstybe ar jos valstybinemis institucijomis, nes mūsų visų sprendžiamos problemos dažniausia neturi nieko bendro su DE JURE" 144 .

Požiūrị ị lietuvių delegaciją rodẻ kiekviena detalè: nors Lietuva ir nebuvo pripažinta valstybė, A. Butkevičiaus vieta prie stalo buvo pažymèta Lietuvos valstybės vèliava ir atitinkamu užrašu.

$1991 \mathrm{~m}$. liepos 2-3 d. A. Butkevičius buvo išvykęs i Belgiją. Jis dalyvavo Europos Parlamento organizuotoje konferencijoje „Europos saugumas ir gynybos ateitis“. Konferencija buvo organizuota siekiant išsiaiškinti Europos valstybiu vadovų ir atsakingu už tarptautinį bendradarbiavimą ir saugumą pareigūnu galimybes suvienytoje Europoje, Europos valstybiu ir JAV santykius saugumo ir gynybos aspektu, aptarti nestabilumo židinių Europoje likvidavimo ir ten kylančiu problemu sprendimo galimybes.

Šioje konferencijoje niekam nekilo abejoniu dèl Baltijos valstybiu reikalavimu būti nepriklausomomis teisėtumo. Buvo pabrèžta, kad Baltijos valstybės turi susitarti su Sovietų Sajunga ir nustatyti naujus tarpusavio santykius, kurie būtų priimtini Europai.

$\overline{{ }^{143} \text { Ten pat. - P. } 28 .}$

${ }^{144}$ A. Butkevičiaus kalba Norvegijoje // KAMEA (byla nenumeruota). 
Konferencijos metu pavyko užmegzti ryšius su Belgijos, Prancūzijos, Anglijos, Graikijos, Danijos saugumo politikos ekspertais.

1991 m. liepos 4 d. A. Butkevičius buvo priimtas Belgijos karališkajame gynybos institute prie Belgijos gynybos ministerijos. Čia buvo aptarta Baltijos valstybių situacija, galimi Lietuvos ir Sovietų Sajungos santykių saugumo politikos srityje modeliai, susitarta dèl konsultaciju Lietuvos ir SSRS derybu metu. Buvo gauti tarptautiniu sutarčiu, reglamentuojančių svetimų kariuomenių bazių statusą, pavyzdžiai, aptarti sovietų kariuomenès išvedimo iš Čekoslovakijos ypatumai.

Liepos $5 \mathrm{~d}$. A. Butkevičius buvo priimtas NATO būstineje Briuselyje, Danijos misijoje. Buvo aptarta situacija Lietuvoje, galimi Sovietų Sajungos ir Lietuvos santykių variantai, NATO bloko valstybiu požiūris į įvairius šių santykių variantus ${ }^{145}$.

Liepos 12-17 d. A. Butkevičius viešèjo Londone. Liepos $13 \mathrm{~d}$. jį prièmė užsienio reikalų ministro specialusis patarëjas $\mathrm{E}$. Biskhamas (Biskham). Susitikimo metu A. Butkevičius informavo E. Biskhamą apie padètį Baltijos valstybèse, pateikẻ atsivežtus iš anksto parengtus dokumentus. Buvo aptartas kai kuriu Didžiosios Britanijos programų pritaikymo Lietuvai galimybės, susitarta informaciją apie Lietuvą teikti reguliariai.

Vèliau ịvyko susitikimas su Karališkojo tarptautiniu ryšiu instituto Tarptautinio saugumo programos vadovu Trevoru Teiloru (Trevor Taylor). Su juo ịvyko atviras pokalbis. Jo metu T. Teiloras patarè Lietuvai kiek galint vengti ginkluotų konfliktų su Sovietų Sajunga. Institutas padovanojo daug vertingos literatūros.

Kiek vẻliau A. Butkevičius skaitė pranešimą Karališkojoje Kamberlio (Camberley) karo akademijoje. Vyko abipusiškai įdomūs susitikimai su nepriklausomais strateginiu tyrimu ekspertais. Taip pat įvyko susitikimas su Gelopo tarptautiniu statistikos tyrimu instituto vadovybe bei Europos valstybèse veikiančių jo filialų direktoriais. Aptarta Lietuvos

${ }^{145}$ A. Butkevičiaus 1991 m. liepos 10 d. Pro memorija //KAA. - F. 1. - Ap. 1. - B. 23. - L. 8182 . 
Respublikos tarptautinio įvaizdžio problema, dalyvavimo tarptautiniu statistiniu tyrimu programose galimybès ir kt.

A. Butkevičiu taip pat prièmè Didžiosios Britanijos Konservatoriu partijos lyderis seras Džefris (Gefry).

Vizito metu taip pat i̇vyko susitikimai su civilinès gynybos sistemos, gelbéjimo bei kitu tarnybu atstovais ${ }^{146}$.

1991 m. rugpjūčio mèn. 5-12 d. A. Butkevičius lankèsi Švedijos Civilinès gynybos departamento kvietimu jo surengtoje konferencijoje. Sioje konferencijoje buvo kalbama apie Baltijos regiono ateitic ir bendru saugumo sistemu perspektyvas, Estijos, Latvijos, Lietuvos vaidmeni jose. Konferencijoje dalyvavo žymiausi Skandinavijos civilinès gynybos specialistai ${ }^{147}$.

Rugpjūčio 8 d. A. Butkevičius pasakè svarbią kalbą „Baltijos valstybiu laisvè ir Skandinavijos saugumas“. Šiame pranešime buvo išsamiai išanalizuota Lietuvos vidaus ir tarptautine padėtis, konferencijos dalyviai supažindinti su Sovietų Sajungos ir jos specialiuju tarnybu veikla siekiant sužlugdyti Lietuvos žmoniu pastangas būti laisviems. Daug dèmesio buvo skirta sovietinès kariuomenès, dislokuotos Lietuvoje, problemoms, kalbèta apie jos Lietuvos saugumui keliamą grèsmę, daromą ekonominę žalą.

Pranešime A. Butkevičius pabrèžè, kad politinis ir ekonominis nestabilumas SSRS kelia grèsmę ne tik Lietuvai, bet ir Skandinavijos valstybèms, todèl visos valstybès turi numatyti bendrą veiklos programą ${ }^{148}$.

Po šios konferencijos A. Butkevičius susitiko su Norvegijos gynybos ministru J. J. Holstu. Tai buvo pirmasis Krašto apsaugos departamento generalinio direktoriaus susitikimas su NATO šalies gynybos ministru. Šiam susitikimui leidimą davė Norvegijos vyriausybẻ. Susitikime buvo aptarti Baltijos šalių ir Lietuvos perspektyvos integruotis į Europos struktūras. Buvo

\footnotetext{
${ }^{146}$ A. Butkevičiaus 1991 m. liepos 19 d. Pro memorija // Ten pat. - L. 184-186.

${ }^{147}$ Šeiberis L. Brifingas AT // Lietuvos aidas. - 1991, rugpjūčio 14.

${ }^{148}$ Butkevičius A. Baltijos valstybių laisvè ir Skandinavijos saugumas // KAMEA (byla nenumeruota).
} 
prieita prie nuomonès, kad tai reikia daryti taikiais būdais, be didesnio konflikto su Rytais, vengiant pralieti kraują ${ }^{149}$.

Vizito į Skandinaviją metu buvo susitarta keistis informacija, reguliariai rengti susitikimus.

1991 m. rugsëjo 10 d. Maskvoje iivyko Lietuvos, Latvijos ir Estijos respubliku atstovų susitikimas su SSRS gynybos ministerijos vadovais.

Lietuvai susitikime atstovavo vicepremjeras Z. Vaišvila, KAD generalinis direktorius A. Butkevičius, Lietuvos Vyriausybės vadovybès valdybos atstovas Z. Rinkevičius, KAD generalinio direktoriaus pavaduotojas N. Vidrinskas ir KAD Savanoriškosios krašto apsaugos tarnybos štabo viršininkas J. Gečas. Latvijos grupei vadovavo premjeras Guodmanis, Estijos - ministras Vare.

Rugsèjo 10 d. ryte Baltijos valstybių atstovai svečiu teisėmis dalyvavo SSRS respubliku atstovu susitikime su Gynybos ministerijos vadovais. Lietuvos ir Estijos atstovai susitikime nekalbejjo.

Po pietu Lietuvos, Latvijos ir Estijos atstovai susitiko su SSRS gynybos ministru E. Šapošnikovu. Buvo sutarta, kad iki $1991 \mathrm{~m}$. pabaigos visi Baltijos valstybiu piliečiai, tarnaujantys sovietinejje kariuomeneje, bus paleisti, taip pat bus atleisti iš šiu respublikų kilę karininkai, pareiškę norą nebetarnauti SSRS ginkluotosiose pajègose.

Susitarta dèl buvusios SSRS civilinès gynybos sistemos, karinių komisariatų turto bei kariniu girininkijų, esančių Lietuvoje, Latvijoje ir Estijoje, perdavimo šiu respublikų žinion.

Nutarta sudaryti mišrias SSRS-Lietuvos, Latvijos ir Estijos komisijas visiems SSRS ginkluotuju pajègų išvedimo iš Baltijos valstybiu klausimams spręsti ${ }^{150}$.

Rugsėjo 23-28 dienomis A. Butkevičius buvo išvykęs ì Daniją, rugsèjo 28-spalio 3 d. - į Angliją ${ }^{151}$.

\footnotetext{
${ }^{149}$ Baltijos šalių gynybos sistema. Ar ji bus sukurta? // Lietuvos aidas. - 1991, rugpjūčio 16. ${ }^{150}$ J. Gečo 1991 m. rugsèjo 14 d. Pro memorija // KAA. - F. 1. - Ap. 1. - B. 14. - L. 9-10. ${ }^{151}$ A. Butkevičiaus 1991 m. gruodžio 6 d. raštas G. Vagnoriui // Ten pat. - B. 29. - L. 178.
} 
Taigi tarptautiniams santykiams, tiesioginiams ryšiams su įvairių šaliu ginkluotosiomis pajègomis Krašto apsaugos departamento vadovybè skyrė didžiuli dėmesị.

\section{Krašto apsaugos departamento likvidavimas}

1991 m. spalio 3 d. Atkuriamasis Seimas prièmé Lietuvos Respublikos Vyriausybės įstatymo pakeitimo ịstatymą, kuriuo remiantis buvo įkurta Krašto apsaugos ministerija.

1991 m. spalio 10 d. Lietuvos Respublikos Aukščiausioji Taryba Audriu Butkevičiu paskyrè krašto apsaugos ministru ${ }^{152}$.

Paskyrus krašto apsaugos ministra, $1991 \mathrm{~m}$. spalio $16 \mathrm{~d}$. Lietuvos Respublikos Vyriausybės nutarimu Nr. 435 Krašto apsaugos departamentas, kaip ịvykdęs užduoti, buvo likviduotas $^{153}$. Spalio $17 \mathrm{~d}$. Ministro Pirmininko pavaduotojo V. Pakalniškio pasirašytu Vyriausybės potvarkiu buvo sudaryta Krašto apsaugos departamento prie Lietuvos Respublikos Vyriausybès likvidavimo komisija. I c ją buvo paskirti A. Butkevičius (pirmininkas), Ž. Aksamitas, V. Bruzgys, V. Česnulevičius, J. Gečas, G. Naujikas, J. Paužolis, Š. Vasiliauskas. Komisijai buvo pavesta iki $1991 \mathrm{~m}$. gruodžio $1 \mathrm{~d}$. atlikti Krašto apsaugos departamento turto inventorizaciją ir pateikti Lietuvos Respublikos Vyriausybei siūlymus dèl tolesnio jo panaudojimo, taip pat spręsti klausimus, susijusius su darbuotoju atleidimu ${ }^{154}$.

Likvidavus Krašto apsaugos departamentą įkurta Krašto apsaugos ministerija tapo šio departamento veiklos tęsëja. Krašto apsaugos departamento pradèta formuoti krašto apsaugos sistema ir Lietuvos kariuomené buvo baigta kurti jau Krašto pasaugos ministerijai vadovaujant. Pirmaisiais

\footnotetext{
${ }^{152}$ Dèl Lietuvos Respublikos krašto apsaugos ministro paskyrimo. Lietuvos Respublikos Aukščiausiosios Tarybos 1991 m. spalio 10 d. nutarimas // Lietuvos Respublikos Aukščiausiosios Tarybos ir Vyriausybès žinios. - 1991. - Nr. 30. - P. 1429.

${ }^{153}$ Dèl kai kurių departamentų prie Lietuvos Respublikos Vyriausybės likvidavimo. $1991 \mathrm{~m}$. spalio 18 d. Lietuvos Respublikos Vyriausybès nutarimas Nr. 435.

${ }^{154}$ Dèl Krašto apsaugos departamento likvidavimo komisijos. Lietuvos Respublikos Vyriausybès 1991 m. spalio 17 d. potvarkis Nr. 746p.
} 
Krašto pasaugos ministerijos egzistavimo mėnesiais iš esmès buvo dirbamas toks pat darbas kaip ir departamente.

\section{Išvados}

Visapusiškai įvertinti, nors ir neilgą, bet gana sudètingą Krašto apsaugos departamento istoriją vis dèlto yra ganètinai sunku. Visu pirma, nors tai ir nesena istorija, dèl to, kad labai trūksta dokumentu, nes, departamentui kuriantis ir pradedant savo veiklą esant gana sudètingai vidaus ir tarptautinei padéčiai, jo veiklos nebuvo stengiamasi dokumentuoti. Daug dokumentų buvo sunaikinta sausio įvykių bei rugpjūčio pučo Maskvoje dienomis. Remtis vien tuo laikotarpiu dirbusių asmenų atsiminimais taip pat negalima, nes jie vis dèlto yra gana subjektyvūs. Tačiau nepaisant viso to, kas čia buvo išdėstyta, galima konstatuoti, kad Krašto apsaugos departamentas jam iškeltus uždavinius daugmaž įvykdè.

Iš esmès buvo sukurtas centrinis aparatas ir karinès administracijos miestuose ir rajonuose. Veikè ne tik komendantūros, bet ir prie jų sukurti komendantiniai būriai. Mokomasis junginys tapo būsimosios reguliariosios kariuomenès pagrindu. Beveik visiškai buvo sukomplektuota Pasienio apsaugos tarnyba. Visoje Lietuvos teritorijoje buvo ikurti Savanoriškosios krašto apsaugos tarnybos padaliniai. I SKAT savanoriais įstojo apie 10 tūkst. Lietuvos vyrų ir moterų. Buvo sukurti aptarnaujančiu tarnybu pagrindai.

Reikia pripažinti, kad departamento veiklos sąlygos buvo gana sunkios, ne visada šiai institucijai palankios. KAD buvo kuriama kaip nauja strktūra, todèl nuo pat pirmujų dienų labai trūko KAD teisinį statusą reglamentuojančių dokumentų. Ši problema, nors ir buvo sprendžiama, tačiau iki galo taip ir liko neišspręsta.

Kaip jau buvo minèta, Aukščiausiosios Tarybos dauguma, ì parlamentą atëję Sajūdžio deleguoti žmonès, atsinešè ir Sajūdžio rinkimų programoje deklaruotas idejas, kad Lietuva turi būti neutrali ir demilitarizuota. Todèl ị karinès struktūros 
kūrimą jie žvelgè atsargiai, ne visada buvo sulaukiama jų paramos. Atvirkščiai, buvo netgi atviro priešiškumo apraiškų.

Naujai kuriamai struktūrai reikẻjo nemažai lèšu, tačiau valstybės ištekliai buvo riboti, todèl per visą Krašto apsaugos departamento gyvavimo laikotarpi jo finansavimas buvo nepakankamas. Dèl nepakankamo finansavimo departamento bei jo naujai kuriamų struktūrų aprūpinimas taip pat buvo nepakankamas, kai kurioms veiklos sritims léšų beveik nebuvo skiriama. Jo dažnai vos užtekdavo menkam departamento darbuotojų darbo užmokesčiui.

Tačiau finansinès problemos neturëjo jokios įtakos departamento darbuotojams. Absoliuti dauguma jų atejo dirbti į kuriamą krašto apsaugos sistemą vadovaudamiesi patriotinèmis nuostatomis ir pasiryžę, jei reikès, dèl Lietuvos laisvès ir nepriklausomybès paaukoti net savo gyvybes. Deja, tenka konstatuoti, kad daug departamento darbuotojų neturëjo karinio pasirengimo, ir tai buvo tam tikra problema. Šią problemą turëjo padèti išspręsti įkurti Karininkų kursai.

Dar viena problema, su kuria nuolat susidurdavo departamento vadovybè, - tai politiniu partijų ir organizacijų mèginimas kištis i departamento veiklą ir jai daryti lemiamą įtaką. Ypač aktyviai bandè kištis Atsargos karininkų sajunga, Šaulių sajunga. Nors su Šaulių sajunga, kaip gimininga organizacija, iš pradžių buvo gana geri santykiai, tačiau dèl kai kurių Šauliu sajungos bei Krašto apsaugos departamento vadovu ambiciju jie gana greitai pakriko, o viso to pasekmè - buvo ikurta beveik analogiška Śaulių sajungai organizacija - Savanoriškoji krašto apsaugos tarnyba. Šis susipriešinimas nieko gera nedavè nei Sauliu sąjungai, nei kuriamai krašto apsaugos sistemai. Tačiau reikia pažymèti, kad Krašto apsaugos departamento vadovybè sugebėjo iki minimumo neutralizuoti politiniu jègu poveiki departamento veiklai.

Ne visada geri santykiai buvo ir su vidaus reikalu sistema. Nors Vidaus reikalų ministerijos ir Krašto apsaugos departamento funkcijos ir uždaviniai buvo skirtingi, į kuriamą naują struktūrą kai kurie Vidaus reikalų ministerijos vadovai 
žiūrëjo kaip į tam tikrą konkurentę. Be to, vyravo nuomonè, kad Krašto apsaugos departamentas yra Lietuvos dešiniuju politinių jëgų atrama, o Vidaus reikalų ministerija - kairiujų. Nors to negalima laikyti absoliučia tiesa, tačiau tai buvo viena iš šių dviejų jẻgos struktūru priešpriešos priežasčių.

Krašto apsaugos departamentas, kaip realią jėgą turinti institucija, buvo nuolatinio okupaciniu SSRS struktūru dèmesio centre. Buvo bandymų ì departamentą infiltruoti KGB darbuotojus, organizuoti prieš departamento vadovybę bei darbuotojus provokacijas.

Dar viena problema, su kuria susidūrè departamentas, buvo susijusi su ginkluote. Iš pradžių departamentas buvo kuriamas kaip neginkluota struktūra, nes, pirma, taip buvo bandoma užkirsti kelią didžiuliam SSRS nepasitenkinimui ir galimoms provokacijoms, antra, nebuvo įstatymu, kuriais remiantis būtu galima apginkluoti krašto apsaugos padalinius. Tik sausio i̇vykiu metu buvo oficialiai gauti pirmieji ginklai iš Lietuvos banko saugyklų, medžiotoju parduotuvių. Tačiau per visą KAD gyvavimo laikotarpi ginklu problema taip ir nebuvo išspręsta.

İteikta 2003-07-08 


\section{Résumé}

\section{Le département de la défense du pays et son activité en 1990 - 1991 \\ Dr. Gintautas Surgailis \\ L'académie militaire de la Lituanie du Général Jonas Žemaitis}

Après la déclaration de l'indépendance de la Lituanie du 11 mars 1990, il était nécessaire d'affermir l'indépendance, acquérir la reconnaissance internationale, organiser le contrôle du pays, des frontières et la défense du pays, des habitants. Le système de la défense du pays était nécessaire, d'autant plus que le gouvernement de l'Union Soviétique n'a pas accepté la déclaration de l'indépendance.

La première tentative de créer l'institution de la défense de la Lituanie a été le 23 mars 1990 dans le Soviet Suprême de la République de la Lituanie en nommant des ministres de la République de la Lituanie. Mais la proposition de nommer le ministre de la défense du pays n'a pas été approuvée.

Le 25 avril 1990, le gouvernement de la République de la Lituanie a créé le Département de la défense du pays auprès du Gouvernement de la Lituanie. Audrius Butkevičius est devenu le directeur général du département.

La fonction du département - former et appliquer la conception de la défense du pays, créer le système de la défense du pays.

Au début de l'activité du département il y avait quelques directions de travail. Créer les services spéciales, capables de défendre les intérêts de la République, le service de la sécurité économique des frontières, les services de sécurité des objets nationaux, créer le système de la sécurité civile de la République et créer les structures de l'armée de la Lituanie.

Les filiales du département de la défense du pays ont été ouvertes dans 7 zones de la Lituanie du 1 juin 1990, le 21 
août - le service de Sécurité créée. Le Gouvernement de la Lituanie a décidé de défendre le marché lituanien et contrôler les frontières, donc le service de la Sécurité des Frontières a été ouvert dans le département de la défense du pays, le 20 décembre - les cours des officiers.

Le 17 janvier 1991 le Soviet Suprême a adopté la loi de Service Volontaire de la Défense du Pays et il a légitimé les structures des volontaires déjà existantes. A la fin du mois de janvier, la division d'instruction du Département de la défense du pays a été créée. Depuis le 1 juin 1991, le service d'immunité commence à travailler ayant le but de présenter les informations nécessaires à l'administration du département.

La situation est devenue compliquée pendant le putsch à Moscou en mois d'août. Mais le putsch a échoué.

Le 3 octobre 1991, le Soviet de L'U.R.S.S. a adopté la décision qu'elle homologue l'indépendance de la Lituanie.

Le 3 octobre 1991 le Soviet Suprême - la Diète de Reconstruction a adopté la loi de changement de la loi du Gouvernement de la République de la Lituanie et le Ministère de la défense nationale a été créé. Le département de défense du pays a été liquidé par la décision du Gouvernement de la République de la Lituanie.

Le Ministère de la défense nationale continuait le travail de rétablissement de l'armée de la Lituanie. 